\title{
19. SOLUTE DISTRIBUTIONS AND STABLE ISOTOPE CHEMISTRY OF INTERSTITIAL WATERS FROM PRYDZ BAY, ANTARCTICA ${ }^{1}$
}

\author{
Steven R. Chambers ${ }^{2}$
}

\begin{abstract}
Leg 119 of the Ocean Drilling Program (ODP) provided the first opportunity to study the interstitial-water chemistry of the eastern Antarctic continental margin. Five sites were cored in a northwest-southeast transect of Prydz Bay that extended from the top of the continental slope to within $30 \mathrm{~km}$ of the coastline. Geological studies of the cores reveal a continental margin that has evolved through terrestrial, glacial, and glacial-marine environments. Chemical and stable isotopic analyses of the interstitial-waters were performed to determine the types of depositional environments and the diagenetic and hydrologic processes that are operating in this unusual marine environment.

Highly compacted glacial sediments provide an effective barrier to the vertical diffusion of interstitial-water solutes. Meteoric water from the Antarctic continent appears to be flowing into Prydz Bay sediments through the sequence of terrestrial sediments that lie underneath the glacial sediments. The large amounts of erosion associated with glacial advances appear to have had the effect of limiting the amount of marine organic matter that is incorporated into the sediments on the continental shelf. Although all of the sites cored in Prydz Bay exhibit depletions in dissolved sulfate with increasing depth, the greatest bacterial activity is associated with a thin layer of diatom ooze that coats the seafloor of the inner bay. Results of alkalinity modeling, thermodynamic calculations, and strontium analyses indicate that (1) ocean bottom waters seaward of Site 740 are undersaturated with respect to both calcite and aragonite, (2) interstitial waters at each site become saturated or supersaturated with respect to calcite and aragonite with increasing depth, (3) precipitation of calcium carbonate reduces the alkalinity of the pore waters with increasing depth, and (4) recrystallization of aragonite to calcite accounts for $24 \%$ of the pore-water strontium. Weathering of unstable terrestrial debris and cation exchange between clay minerals and pore fluids are the most probable chemical processes affecting interstitialwater cation gradients.
\end{abstract}

\section{INTRODUCTION}

Interstitial waters of marine sediments are sensitive recorders of chemical and physical processes occurring below the seafloor. Water is a ubiquitous component of sediments that reside within ocean basins. In fact, it is commonly the most abundant phase present. A variety of organisms exchange oxidizing agents in pore fluids with metabolic byproducts during the oxidation of organic matter. In particular, the activities of bacteria are a major controlling influence on the oxidation-reduction potential of seafloor sediments. Inorganic constituents of the sediments also interact with the pore waters as they attempt to equilibrate with their slowly changing environment. These reactions create chemical potential gradients that drive the diffusion of ions through interstitial waters. Compaction by overburden, the movement of lithospheric plates, hydrothermal activity, and groundwater flow on continental margins are physical processes that can impact the composition of interstitial waters through advection and mixing. Thus, a multitude of processes may be responsible for the ultimate composition of the waters within marine sediments. The purpose of interstitial-water chemical studies is to elucidate these processes through a variety of analytical techniques, the application of chemical principles, and the assimilation of geologic observations.

Leg 119 of the Ocean Drilling Program (ODP) provided the first opportunity to study the interstitial-water chemistry of the eastern Antarctic continental margin. Five sites were cored in a northwest-southeast transect of Prydz Bay in an attempt to unravel the glacial history of eastern Antarctica. The transect extended from the top of the continental slope to within $30 \mathrm{~km}$ of

${ }^{1}$ Barron, J., Larsen, B., et al., 1991. Proc. ODP, Sci. Results, 119: College Station, TX (Ocean Drilling Program).

2 Department of Geology, Stanford University, Stanford, CA 94305, U.S.A. the coastline. Sedimentation in Prydz Bay is controlled by a major glacier system that has apparently existed since at least the early Oligocene (Leg 119 Scientific Party, 1988; Barron, Larsen, et al., 1989). Water depths in excess of $800 \mathrm{~m}$ testify to the intense scouring of the continental shelf by ancient glaciers. The present climate covers the bay with sea ice 11 months of the year, placing tight temporal restrictions on marine productivity and pelagic sedimentation. Interstitial-water studies were performed in conjunction with Leg 119 to determine the types of depositional environments and the diagenetic and hydrologic processes that are operating in this unique marine environment.

\section{GEOLOGIC SETTING OF PRYDZ BAY}

Prydz Bay is located on the eastern side of the Antarctic continent at approximately $68^{\circ} \mathrm{S}$ and $75^{\circ} \mathrm{E}$ (Fig. 1). The bay is floored by the seaward extension of the Lambert Graben, a structural feature that is thought to have formed during the Permian (Stagg, 1988). Approximately $20 \%$ of the East Antarctic Ice Sheet drains into Prydz Bay through the Lambert Glacier (Fig. 1; Hambrey et al., this volume). The sedimentologic and biostratigraphic studies of Leg 119 scientists indicate that sedimentation in Prydz Bay has been controlled by this extensive glacial system since at least the early Oligocene (Leg 119 Scientific Party, 1988; Barron, Larsen, et al., 1989). Consolidation measurements on Prydz Bay sediments suggest that glacial advances have removed extensive portions of the sedimentary record (Solheim et al., this volume). Glacial erosion and loading of the shelf has resulted in highly overcompacted sediments and water depths in excess of $1000 \mathrm{~m}$ (Stagg, 1985; Barron, Larsen, et al., 1989; Solheim et al., this volume). Thus, the sediment-interstitial-water system in Prydz Bay is unusual in that ice, not water, has capped the sequence during much of its history. In addition, overcompaction of the sediments should greatly inhibit the diffusion rate of dissolved ions. 


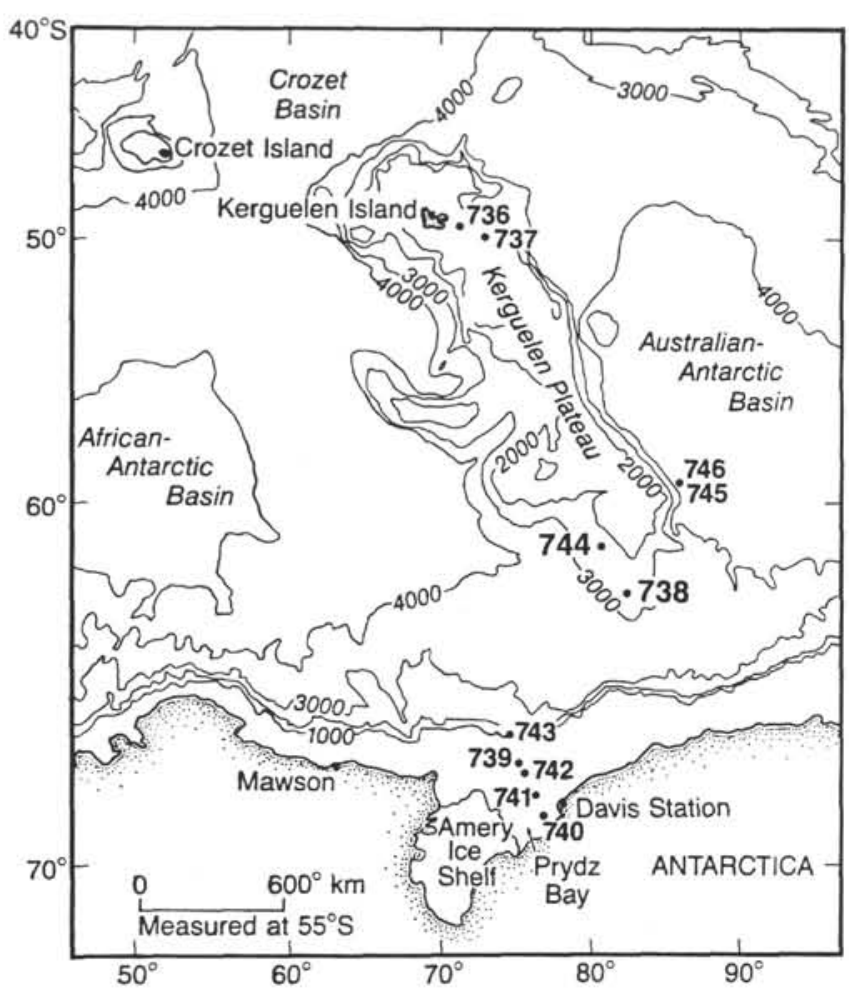

Figure 1. Location map of the Kerguelen Plateau and Prydz Bay with ODP Leg 119 and 120 coring sites and 1000-m bathymetric contours (from Barron, Larsen, et al., 1989).

The five sites cored in Prydz Bay during Leg 119 reveal a continental margin that has evolved through terrestrial, glacial, and glacial-marine environments. Figure 2 is a geologic cross section showing site locations and the major lithologic units encountered in Prydz Bay. A fluvial "red bed" sequence cored at Site 740 consists of sandstones with interbedded siltstones and claystones of unknown age that overlie a basement composed of Precambrian igneous and metamorphic rocks. Younger fluvial sediments were also cored at Site 741 . The latter sediments contain an abundance of terrestrial organic matter in the form of plant fragments or "coal," which together with the fluvial sediments at Site 740 , indicate a temperate, terrestrial environment in the Prydz Bay region prior to glaciation. A thick sequence of glacial sediments dominates the outer shelf and blankets the bottom of Prydz Bay. The bulk of these sediments consists of poorly sorted sand-silt-clays known as "diamictons" if unlithified and "diamictites" if lithified. The scarcity of biogenic material in the glacial sediments has made age determinations difficult, but the oldest appear to be at least early Oligocene in age (Barron, Larsen, et al., 1989). Discrete packages of prograding sediments comprise the lowermost portion of the glacial sequence. The prograding sediments represent a depositional environment in which the ice margin lies close to the shelf edge (Hambrey et al., this volume). The shallowest diamictites are flat lying and indicate a greater marine influence in the area of deposition (Hambrey et al., this volume). Holocene sedimentation in Prydz Bay consists of diatom oozes with glacial-marine clays and minor ice-rafted debris (Barron, Larsen, et al., 1989).

Sedimentation rates in Prydz Bay are difficult to ascertain because of the lack of biostratigraphic data. Diatom stratigraphy at Site 739 suggests that the Neogene glacial sediments accumulated at a minimum rate of $19 \mathrm{~m} / \mathrm{m}$.y. (Barron, Larsen, et al., 1989). Cranston (this volume) proposed a new method for estimating sedimentation rates using interstitial-water ammonium and sulfate gradients. This technique is based on the strong correlations between sedimentation rates, organic carbon contents of sediments, and dissolved ammonium and sulfate gradients in the uppermost few hundred meters at other ODP sites. Using the data collected in the present study, Cranston (this volume) estimated that the glacial sediments in Prydz Bay accumulated at rates of $20-30 \mathrm{~m} / \mathrm{m}$.y. Once again, these are probably minimum rates as the Cranston technique does not correct for compaction of the sediments and it assumes continuous sedimentation.

An interesting aspect of the Prydz Bay region is that ancient sedimentation rates may not be an important factor in determining the organic carbon content of the glacial sediments and the biochemistry of the pore-fluid system. Ordinarily, sedimentation rates are positively correlated with the organic carbon content of marine sediments. An exception may be found in regions of extremely rapid sedimentation and/or low biological productivity, which may result in the dilution of the biogenic material. However, much of the glacial sediment in Prydz Bay was deposited directly beneath the Lambert Glacier, precluding the deposition of marine organic matter. This scenario is supported by the preponderance of type III kerogen discovered during shipboard Rock-Eval analyses of the diamictons and diamictites (Barron, Larsen, et al., 1989). Very little of the organic matter in the diamicts has a marine source.

\section{METHODS}

\section{Sampling}

Interstitial-water samples were obtained from each of the five sites cored in Prydz Bay during Leg 119. The routine ODP sampling protocol calls for one 5- to $10-\mathrm{cm}$ whole-round minicore sample $(170-340 \mathrm{~mL})$ to be taken from every third core for pore-water extraction. This sampling program yielded 40 samples for chemical studies of interstitial waters. An additional 52 samples were retrieved from Site 739 by means of a new highresolution sampling technique which called for 10 -mL sediment samples to be removed at 1 - to 2 -m intervals (Cranston, this volume).

The ODP method for extracting interstitial waters from core samples involves a squeezing procedure incorporating a hydraulic press. An outline and critique of the sample-handling procedures employed in this study can be found in the paper by Chambers and Cranston in this volume. All of the samples were squeezed at room temperature and under normal atmospheric conditions.

\section{Analytical Methods}

\section{Chemical Analyses}

The shipboard water-chemistry program included analyses for $\mathrm{pH}$, alkalinity, salinity, chloride, magnesium, calcium, sulfate, ammonium, phosphate, and aqueous silica. Details of the shipboard analytical methods have been published in a procedure manual by Gieskes and Peretsman (1986). Salinity (total dissolved solids) determinations were made with an AO Scientific Instruments optical refractometer. Alkalinity and $\mathrm{pH}$ were determined by means of a Metrohm autotitrator, a Brinkman combination $\mathrm{pH}$ electrode, and a computer for data collection and Gran function calculations. Calcium, magnesium, and chloride concentrations were measured by wet chemical titrations. A Dionex ion chromatograph supplied sulfate concentrations and a Bausch and Lomb Spectronic 1001 spectrophotometer yielded phosphate, ammonium, and aqueous silica concentrations. Sodium and potassium analyses of the interstitial waters were determined using a shore-based Thermo Jarrell Ash 12E atomic 


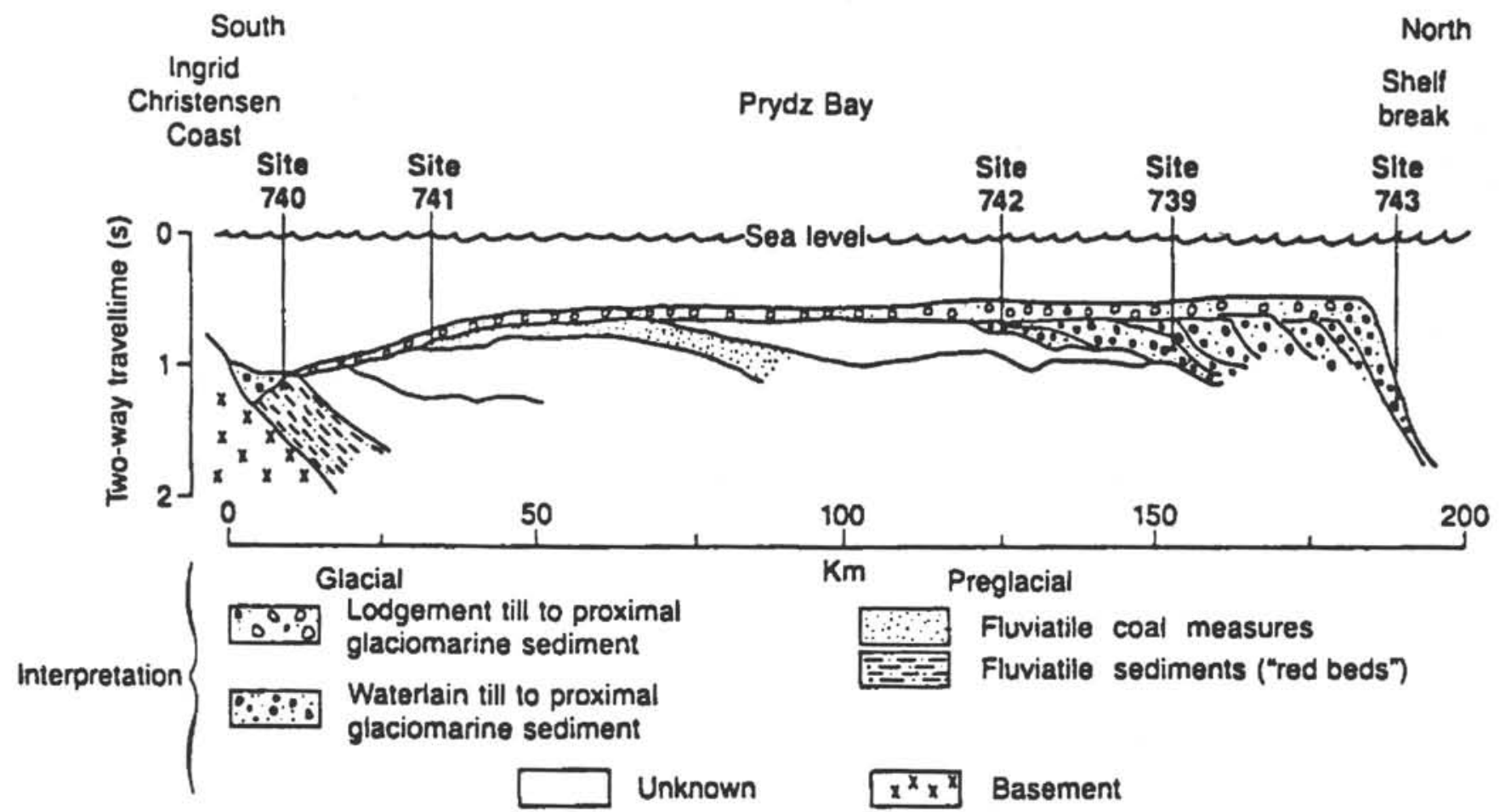

Figure 2. Geological cross section through the Prydz Bay drill sites based on seismic data and core observations (from Hambrey et al., this volume).

absorption spectrophotometer (see Chambers and Cranston, this volume, for details). IAPSO (International Association for the Physical Sciences of the Ocean) standard seawater was the primary standard for calcium, magnesium, and sulfate determinations. The remaining analyses were standardized with prepared standards (see Gieskes and Peretsman, 1986). An evaluation of the analytical precision and accuracy of these techniques can be found in Chambers and Cranston (this volume).

Subsequent to freeze drying, small pieces of the squeezed sediments were removed for shipboard determinations of organic carbon and carbonate contents. A Coulometrics 5020 Total Carbon Apparatus coupled with a model $5010 \mathrm{CO}_{2}$ Coulometer was used for these analyses.

\section{Stable Isotope Analyses}

Oxygen and hydrogen isotope analyses of the water solvent were performed to determine the origin and chemical history of the Prydz Bay pore fluids. The origin of water in sediments places a fundamental constraint on its ${ }^{18} \mathrm{O}$ and ${ }^{2} \mathrm{H}$ content. Ocean waters display a relatively narrow range of isotopic compositions relative to meteoric waters (Epstein and Mayeda, 1953; Craig, 1961). Meteoric waters are generally depleted in ${ }^{18} \mathrm{O}$ and ${ }^{2} \mathrm{H}$ relative to ocean waters, due to the preferential evaporation of ${ }^{1} \mathrm{H}_{2}{ }^{16} \mathrm{O}$. Heavy isotope depletion in meteoric waters is positively correlated with latitude, thus Antarctic precipitation is one of the isotopically lightest natural sources of water. This is of particular importance to the study of interstitial waters in Prydz Bay sediments, some of which may be experiencing the incursion of terrestrial groundwater (Barron, Larsen, et al., 1989). Large-scale continental glaciation at high latitudes affects the isotopic composition of the oceans by sequestering large amounts of ${ }^{16} \mathrm{O}$ and ${ }^{1} \mathrm{H}$ from the global hydrologic cycle. If solid-fluid isotope fractionation has been negligible and the effects of diffusion minimal, marine interstitial waters may reflect the isotopic composition of ancient oceans (Bath and Shackleton, 1984). However, oxygen and hydrogen isotopes in pore water can also be fractionated during reactions with solid phases.
Oxygen isotope analyses of the interstitial-water samples were performed using standard $\mathrm{CO}_{2}$ equilibration techniques (Epstein and Mayeda, 1953). Samples were transported from the ship in flame-sealed glass ampoules. The typical sample size for these analyses was $1 \mathrm{~mL}$. Oxygen isotope ratios of the equilibrated $\mathrm{CO}_{2}$ were measured with a gas source mass spectrometer. An analytical precision of $\pm 0.11 \%$ was determined by means of replicate analyses of three standards.

Microgram quantities of the pore-water samples were reacted with hot zinc to liberate $\mathrm{H}_{2}$ gas for hydrogen isotope analysis. The reduction of water with zinc for hydrogen isotope analysis has received a great deal of attention because of its high hydrogen yield and low time investment relative to the standard method employing uranium (Friedman, 1953; Coleman et al., 1982; Kendall and Coplen, 1985; Tanweer et al., 1988). In this study, 4 $\mu \mathrm{L}$ of water was frozen onto fine-grained zinc shot and flamesealed in 6-mm outside diameter pyrex tubing while under vacuum. The water and zinc reagents were then reacted at $450^{\circ} \mathrm{C}$ for $1 \mathrm{hr}$ to produce hydrogen gas for mass spectrometric analysis. All of the hydrogen isotope data reported in this paper represent the average of replicate analyses. The average standard deviation of 80 replicate analyses is $0.7 \%$.

\section{RESULTS}

The combined effects of low water content and poor core recovery have resulted in an incomplete record of the interstitialwater chemistry of the Prydz Bay sediments. Frequent traverses of the continental shelf by previous incarnations of the Lambert glacier have produced hard, overcompacted, and poorly sorted glacigenic sediments. The majority of the sediments recovered from Prydz Bay contained less than $20 \%$ water (wet wt $\%$ ). An abundance of large clasts in the glacial sediments hindered the extraction of the small amounts of water by the squeezing method. As a result, the volume of water obtained from the sediments was often too small to allow the full compliment of chemical analyses. Thus, the interstitial-water chemistry data set for Prydz Bay is sketchy, but it provides much important informa- 
tion about the chemical environment of this unusual sedimentary system.

The chemical data produced by analyses of sediments and pore waters from Prydz Bay are listed in Tables 1 through 3. The paper by Chambers and Cranston in this volume provides the equations used to calculate the charge imbalance (Table 1). An excess of cations over anions results in a positive charge imbalance. Calculations suggest that the maximum charge imbalance due to systematic errors in the analytical techniques is $2.3 \%$ (Chambers and Cranston, this volume). Only 6 of the 79 Leg 119 water samples for which charge imbalances were calculated are in excess of this value. The mean charge imbalance is $+0.4 \%(n=79)$, and the mean of the absolute values of the charge imbalances is $1.0 \%(n=79$; Chambers and Cranston, this volume).
The oxygen and hydrogen isotope compositions of the Prydz Bay pore-fluid samples are shown in Table 4. The isotopic composition of the water samples is represented by the standard delta $(\partial)$ notation:

$$
\partial\left({ }^{18} \mathrm{O},{ }^{2} \mathrm{H}\right)=\frac{\mathrm{R}_{\text {sample }}-\mathrm{R}_{\text {standard }}}{\mathrm{R}_{\text {standard }}} \times 1000,
$$

where $\mathrm{R}$ is the ratio of the heavy isotope to the light isotope. All of the isotope data reported in this study represent per mil deviations from the Standard Mean Ocean Water (SMOW) standard.

Any discussion of interstitial-water chemistry would be incomplete without some knowledge of the chemistry and mineralogy of the coexisting sediments. The following discussion will

Table 1. Organic carbon and calcium carbonate contents of sediment minicores and interstitial-water salinity, chloride concentration, and charge-imbalance data for Leg 119 Prydz Bay sites.

\begin{tabular}{|c|c|c|c|c|c|c|}
\hline $\begin{array}{c}\text { Sample } \\
\text { (core, section) }\end{array}$ & $\begin{array}{l}\text { Depth } \\
\text { (mbsf) }\end{array}$ & $\begin{array}{c}\text { Organic } \\
\text { carbon } \\
(\text { dry } w t \%)\end{array}$ & $\begin{array}{c}\mathrm{CaCO}_{3} \\
(\text { dry } w t \%)\end{array}$ & $\begin{array}{l}\text { Salinity } \\
(\% 0)\end{array}$ & $\begin{array}{l}\mathrm{Cl}^{-} \\
(\mathrm{mM})\end{array}$ & $\begin{array}{c}\text { Charge } \\
\text { imbalance } \\
(\%)\end{array}$ \\
\hline \multicolumn{7}{|l|}{$119.739 \mathrm{C}$ - } \\
\hline $4 \mathrm{R}-2$ & 27.05 & 0.43 & 0.5 & 36.2 & 562 & n.d. \\
\hline $16 \mathrm{R}-2$ & 133.20 & 1.34 & 0.7 & 35.5 & 565 & n.d.. \\
\hline $19 \mathrm{R}-2$ & 147.60 & 1.61 & 0.1 & 34.4 & 554 & n.d. \\
\hline $22 \mathrm{R}-2$ & 162.20 & 1.86 & 0.6 & 35.2 & 560 & n.d. \\
\hline $25 R-1$ & 174.82 & 0.69 & 2.2 & 34.0 & 563 & n.d. \\
\hline $28 \mathrm{R}-3$ & 206.90 & 0.64 & 0.6 & 34.5 & 552 & n.d. \\
\hline $34 \mathrm{R}-2$ & 263.30 & 0.55 & 1.3 & 34.0 & 558 & -1.0 \\
\hline $38 \mathrm{R}-2$ & 301.80 & 0.87 & 1.5 & 33.8 & 553 & n.d. \\
\hline $41 \mathrm{R}-2$ & 330.70 & 0.71 & 0.9 & 33.8 & 551 & n.d. \\
\hline $44 \mathrm{R}-1$ & 358.20 & 0.70 & 0.8 & 34.4 & 561 & n.d. \\
\hline $48 \mathrm{R}-1$ & 397.00 & 0.64 & 0.9 & 33.5 & 552 & 0.1 \\
\hline $50 \mathrm{R}-1$ & 416.30 & n.d. & n.d. & 33.0 & 546 & n.d. \\
\hline $54 \mathrm{R}-1$ & 445.30 & 0.39 & 0.4 & 33.5 & 553 & n.d. \\
\hline $58 \mathrm{R}-1$ & 464.60 & n.d. & n.d. & 33.5 & 556 & n.d. \\
\hline \multicolumn{7}{|l|}{$119-740 \mathrm{~A}-$} \\
\hline 3R-2 & 16.65 & 1.37 & 0.2 & 35.0 & 541 & 1.1 \\
\hline $8 \mathrm{R}-3$ & 61.00 & 0.07 & 0.1 & 32.5 & 507 & n.d. \\
\hline $11 R-1$ & 72.30 & 0.03 & 0.2 & 31.5 & 512 & n.d. \\
\hline 22R-1 & 130.20 & 0.03 & 0.1 & 32.2 & 517 & n.d. \\
\hline $25 \mathrm{R}-1$ & 159.20 & 0.04 & 0.0 & 33.8 & 519 & n.d. \\
\hline $31 \mathrm{R}-6$ & 223.30 & 0.03 & 0.1 & 30.5 & 482 & n.d. \\
\hline \multicolumn{7}{|l|}{$119-740 \mathrm{~B}-$} \\
\hline IR-1 & 1.45 & 1.40 & 0.1 & 35.0 & 549 & 0.6 \\
\hline \multicolumn{7}{|l|}{$119-741 \mathrm{~A}-$} \\
\hline IR-2 & 2.95 & 0.22 & 0.0 & 35.0 & 556 & 0.2 \\
\hline $4 R-2$ & 26.80 & 0.17 & 0.0 & 35.5 & 561 & n.d. \\
\hline $13 R-3$ & 115.20 & 2.40 & 0.1 & 34.2 & 546 & n.d. \\
\hline \multicolumn{7}{|l|}{$119-742 \mathrm{~A}-$} \\
\hline 1R-2 & 2.95 & 0.31 & 0.1 & 35.5 & 551 & 2.5 \\
\hline $3 R-1$ & 15.39 & 0.29 & 0.0 & 35.7 & 550 & n.d. \\
\hline $8 \mathrm{R}-2$ & 58.40 & 1.03 & 0.4 & 36.0 & 561 & n.d. \\
\hline $11 \mathrm{R}-2$ & 87.30 & 0.40 & 0.5 & 35.5 & 558 & n.d. \\
\hline $14 \mathrm{R}-2$ & 116.20 & 0.41 & 0.2 & 34.8 & 558 & 1.1 \\
\hline $17 \mathrm{R}-5$ & 149.70 & 1.41 & 0.3 & 34.2 & 545 & n.d. \\
\hline $20 \mathrm{R}-2$ & 174.20 & 0.85 & 0.8 & 34.2 & 540 & n.d. \\
\hline $23 R-4$ & 206.20 & 0.57 & 0.5 & 33.8 & 536 & n.d. \\
\hline $27 R-4$ & 244.70 & 0.67 & 0.4 & 33.5 & 555 & n.d. \\
\hline $30 \mathrm{R}-4$ & 273.65 & 0.57 & 0.4 & 33.0 & 546 & n.d. \\
\hline $33 R-4$ & 302.60 & 0.61 & 0.5 & 32.8 & 550 & n.d. \\
\hline \multicolumn{7}{|l|}{$119-743 \mathrm{~A}-$} \\
\hline $1 \mathrm{H}-1$ & 0.94 & 0.20 & 0.1 & 34.5 & 544 & 0.6 \\
\hline $3 \mathrm{H}-1$ & 3.35 & 0.28 & 0.2 & 35.2 & 547 & 1.6 \\
\hline $9 \mathrm{H}-1$ & 41.65 & 0.31 & 0.1 & 35.2 & 564 & 0.9 \\
\hline
\end{tabular}


Table 2. Interstitial-water nutrient data for Leg 119 Prydz Bay sites.

\begin{tabular}{|c|c|c|c|c|c|c|c|}
\hline $\begin{array}{c}\text { Sample } \\
\text { (core, section) }\end{array}$ & $\begin{array}{l}\text { Depth } \\
\text { (mbsf) }\end{array}$ & $\mathrm{pH}$ & $\begin{array}{l}\text { Alkalinity } \\
(\mathrm{meq} / \mathrm{L})\end{array}$ & $\begin{array}{l}\mathrm{SO}_{4}^{2-} \\
(\mathrm{mM})\end{array}$ & $\begin{array}{l}\mathrm{NH}_{4}^{+} \\
(\mu \mathrm{M})\end{array}$ & $\begin{array}{c}\mathrm{HPO}_{4}^{2-} \\
(\mu \mathrm{M})\end{array}$ & $\begin{array}{l}\mathrm{SiO}_{2} \\
(\mu \mathrm{M})\end{array}$ \\
\hline \multicolumn{8}{|l|}{$119-739 \mathrm{C}$} \\
\hline $4 R-2$ & 27.05 & n.d. & n.d. & 26.7 & 0.14 & n.d. & 136 \\
\hline $16 \mathrm{R}-2$ & 133.20 & n.d. & n.d. & 17.7 & 0.46 & 1 & 140 \\
\hline $19 \mathrm{R}-2$ & 147.60 & n.d. & n.d. & 13.6 & 0.69 & n.d. & 482 \\
\hline $22 \mathrm{R}-2$ & 162.20 & n.d. & n.d. & 17.4 & 0.69 & n.d. & 237 \\
\hline $25 \mathrm{R}-1$ & 174.82 & 7.9 & 3.85 & 11.9 & 0.90 & 0 & 489 \\
\hline $28 \mathrm{R}-3$ & 206.90 & 8.1 & 3.60 & 10.8 & 1.05 & n.d. & 412 \\
\hline $31 R-3$ & 235.80 & 7.8 & 4.12 & 9.4 & 1.03 & 1 & 592 \\
\hline $34 \mathrm{R}-2$ & 263.30 & 7.9 & 3.99 & 8.4 & 1.09 & 0 & 615 \\
\hline $38 \mathrm{R}-2$ & 301.80 & 7.9 & 3.38 & 8.4 & 1.08 & 0 & 485 \\
\hline $41 R-2$ & 330.70 & n.d. & n.d. & 10.8 & 0.91 & 0 & 98 \\
\hline $44 R-1$ & 358.20 & n.d. & n.d. & 10.5 & 1.03 & 0 & 94 \\
\hline $48 \mathrm{R}-1$ & 397.00 & 8.1 & 2.15 & 8.1 & 0.94 & 0 & 106 \\
\hline $50 \mathrm{R}-1$ & 416.30 & 8.0 & 3.02 & 8.1 & 0.76 & 0 & 175 \\
\hline $54 \mathrm{R}-1$ & 445.30 & 8.2 & 2.22 & 6.0 & 1.01 & 0 & 98 \\
\hline $58 \mathrm{R}-1$ & 464.60 & n.d. & n.d. & 6.0 & 1.01 & 0 & 79 \\
\hline \multicolumn{8}{|l|}{$119-740 \mathrm{~A}-$} \\
\hline $3 R-2$ & 16.65 & 8.0 & 20.15 & 15.4 & 2.16 & 130 & 653 \\
\hline $8 \mathrm{R}-3$ & 61.00 & n.d. & n.d. & 15.0 & 0.34 & n.d. & 134 \\
\hline $11 R-1$ & 72.30 & 7.9 & 0.69 & 0.9 & 0.78 & 0 & 38 \\
\hline $17 \mathrm{R}-1$ & 101.30 & 7.7 & 0.94 & 2.6 & 0.72 & 0 & n.d. \\
\hline $22 R-1$ & 130.20 & n.d. & n.d. & 1.7 & 0.51 & n.d. & 106 \\
\hline $25 R-1$ & 159.20 & 7.5 & 0.87 & 8.6 & 0.43 & 0 & 106 \\
\hline $31 R-6$ & 223.30 & 7.4 & 1.07 & 5.1 & 0.24 & 0 & 49 \\
\hline \multicolumn{8}{|l|}{ 119-740B- } \\
\hline 1R-1 & 1.45 & 7.6 & 23.19 & 12.8 & 2.04 & 152 & 700 \\
\hline \multicolumn{8}{|l|}{$119-741 \mathrm{~A}-$} \\
\hline IR-2 & 2.95 & 7.4 & 3.00 & 26.5 & 0.04 & 12 & 556 \\
\hline $4 \mathrm{R}-2$ & 26.80 & n.d. & n.d. & 22.8 & 0.16 & n.d. & 85 \\
\hline $13 R-3$ & 115.20 & n.d. & n.d. & 18.7 & 0.14 & n.d. & 103 \\
\hline \multicolumn{8}{|l|}{$119-742 \mathrm{~A}-$} \\
\hline 1R-2 & 2.95 & 7.5 & 4.74 & 28.9 & 0.14 & 19 & 694 \\
\hline 3R-1 & 15.39 & 7.6 & 3.98 & 29.5 & 0.18 & 5 & 672 \\
\hline $8 \mathrm{R}-2$ & 58.40 & 8.1 & 2.16 & 27.8 & 0.08 & 2 & 192 \\
\hline $11 R-2$ & 87.30 & 8.1 & 1.32 & 23.4 & 0.09 & 1 & 167 \\
\hline $14 \mathrm{R}-2$ & 116.20 & 8.2 & 1.60 & 21.2 & 0.14 & 1 & 304 \\
\hline $17 R-5$ & 149.70 & 8.4 & 2.16 & 20.1 & 0.26 & 0 & 129 \\
\hline 20R-2 & 174.20 & n.d. & n.d. & 17.8 & 0.28 & 0 & 171 \\
\hline $23 R-4$ & 206.20 & 8.0 & 2.22 & 13.4 & 0.50 & 0 & 80 \\
\hline $27 R-4$ & 244.70 & 8.1 & 2.22 & 10.7 & 0.64 & n.d. & 86 \\
\hline $30 \mathrm{R}-4$ & 273.65 & 8.1 & 2.58 & 10.1 & n.d. & 0 & 122 \\
\hline $33 R-4$ & 302.60 & 8.3 & 2.00 & 6.8 & n.d. & n.d. & 78 \\
\hline \multicolumn{8}{|l|}{$119-743 \mathrm{~A}$} \\
\hline $1 \mathrm{H}-1$ & 0.94 & 7.3 & 3.12 & 30.5 & 0.08 & 6 & 419 \\
\hline $3 \mathrm{H}-1$ & 3.35 & 7.7 & 2.97 & 28.5 & 0.06 & 3 & 386 \\
\hline $9 \mathrm{H}-1$ & 41.65 & 7.8 & 2.59 & 22.5 & 0.23 & 3 & 520 \\
\hline
\end{tabular}

incorporate sediment chemistry for Site 739 from Cranston (this volume), mineralogy for Sites 739 and 742 from Hambrey et al. (this volume), and core descriptions reported by the Leg 119 sedimentologists (Barron, Larsen, et al., 1989).

\section{Site 739}

Approximately $487 \mathrm{~m}$ of late Eocene(?)/early Oligocene through Quaternary age glacial sediments was drilled near the shelf edge in outer Prydz Bay. The sedimentary sequence recovered at Site $739\left(67^{\circ} 16.57^{\prime} \mathrm{S}, 75^{\circ} 04.91^{\prime} \mathrm{E}\right.$, water depth $=412.4$ $\mathrm{m})$ consists primarily of overconsolidated diamictons and diamictites with unusual variations in their physical properties (Barron, Larsen, et al., 1989; Solheim et al., this volume). Porosities and water contents actually increase with depth below $170 \mathrm{mbsf}$. From 256 mbsf to the bottom of the cored sequence, the more typical trends of decreasing porosities and water contents are once again encountered. These variations in sediment physical properties are primarily caused by changes in average grain size and lithology that may be associated with glacial advances and retreats (Solheim et al., this volume). They also have a significant effect upon mass transfer through the interstitial waters.

Variations in sediment porosity at Site 739 are closely correlated with changes in the electrical resistivity of the sequence as measured by downhole logging (Fig. 3). The downward transition to more porous sediments near $175 \mathrm{mbsf}$ is accompanied by a eight-fold decrease in electrical resistivity (Barron, Larsen, et al., 1989). As bulk-sediment diffusion coefficients are inversely proportional to the wet-sediment resistivity (Berner, 1980; see the "Discussion" section, and Chambers and Cranston, this volume), the rate of ionic diffusion through the sediment-porewater system should increase by a factor of 8 below this transition zone. Resistivity values increase from 300 to 486 mbsf, sug- 
Table 3. Interstitial-water major cation concentrations for Leg 119 Prydz Bay sites.

\begin{tabular}{lllllr}
\hline $\begin{array}{c}\text { Sample } \\
\text { (core, section) }\end{array}$ & $\begin{array}{c}\text { Depth } \\
\text { (mbsf) }\end{array}$ & $\begin{array}{c}\mathrm{Na}^{+} \\
(\mathrm{mM})\end{array}$ & $\begin{array}{c}\mathrm{Mg}^{2+} \\
(\mathrm{mM})\end{array}$ & $\begin{array}{c}\mathrm{Ca}^{2+} \\
(\mathrm{mM})\end{array}$ & $\begin{array}{c}\mathrm{K}^{+} \\
(\mathrm{mM})\end{array}$ \\
\hline 119-739C- & & & & & \\
4R-2 & 27.05 & n.d. & 42.6 & 19.5 & n.d. \\
16R-2 & 133.20 & n.d. & 40.6 & 17.9 & n.d. \\
19R-2 & 147.60 & n.d. & 37.7 & 15.6 & n.d. \\
22R-2 & 162.20 & n.d. & 42.4 & 14.3 & n.d. \\
25R-1 & 174.82 & n.d. & 38.8 & 14.6 & n.d. \\
28R-3 & 206.90 & n.d. & 36.6 & 13.9 & n.d. \\
31R-3 & 235.80 & n.d. & 37.3 & 14.0 & n.d. \\
34R-2 & 263.30 & 470 & 36.0 & 14.1 & 2.6 \\
38R-2 & 301.80 & n.d. & 35.0 & 13.9 & n.d. \\
41R-2 & 330.70 & n.d. & 35.8 & 13.2 & n.d. \\
44R-1 & 358.20 & n.d. & 33.1 & 13.8 & n.d. \\
48R-1 & 397.00 & 483 & 33.1 & 13.4 & 2.4 \\
50R-1 & 416.30 & n.d. & 31.8 & 13.8 & n.d. \\
54R-1 & 445.30 & n.d. & 28.3 & 13.8 & n.d. \\
58R-1 & 464.60 & n.d. & 26.1 & 14.4 & n.d.
\end{tabular}

119-740A-

$\begin{array}{lrlrrr}\text { 3R-2 } & 16.65 & 479 & 52.0 & 9.0 & 9.6 \\ \text { 8R-3 } & 61.00 & \text { n.d. } & 41.9 & 35.2 & \text { n.d. } \\ \text { 11R-1 } & 72.30 & \text { n.d. } & 27.8 & 41.6 & \text { n.d. } \\ \text { 17R-1 } & 101.30 & 364 & 24.5 & 55.8 & 1.3 \\ 22 \text { R-1 } & 130.20 & \text { n.d. } & 19.2 & 64.5 & \text { n.d. } \\ \text { 25R-1 } & 159.20 & \text { n.d. } & 18.9 & 75.5 & \text { n.d. } \\ \text { 31R-6 } & 223.30 & \text { n.d. } & 13.1 & 76.0 & \text { n.d. }\end{array}$

119-740B-

\begin{tabular}{|c|c|c|c|c|c|}
\hline 1R-1 & 1.45 & 483 & 50.2 & 8.9 & 9.4 \\
\hline \multicolumn{6}{|l|}{$119-741 \mathrm{~A}-$} \\
\hline $1 R-2$ & 2.95 & 488 & 50.2 & 10.5 & 11.6 \\
\hline $4 \mathrm{R}-2$ & 26.80 & n.d. & 44.8 & 13.8 & n.d. \\
\hline $13 R-3$ & 115.20 & n.d. & 37.0 & 16.5 & n.d. \\
\hline \multicolumn{6}{|l|}{$119-742 \mathrm{~A}-$} \\
\hline 1R-2 & 2.95 & 517 & 51.0 & 10.7 & 11.8 \\
\hline $3 R-1$ & 15.39 & n.d. & 50.4 & 12.9 & n.d. \\
\hline $8 R-2$ & 58.40 & n.d. & 39.9 & 23.6 & n.d. \\
\hline $11 R-2$ & 87.30 & n.d. & 36.8 & 25.5 & n.d. \\
\hline $14 \mathrm{R}-2$ & 116.20 & 500 & 36.8 & 23.8 & 2.3 \\
\hline $17 \mathrm{R}-5$ & 149.70 & n.d. & 39.2 & 19.1 & n.d. \\
\hline $20 \mathrm{R}-2$ & 174.20 & n.d. & 41.6 & 17.1 & n.d. \\
\hline $23 R-4$ & 206.20 & n.d. & 36.1 & 15.0 & n.d. \\
\hline $27 R-4$ & 244.70 & n.d. & 33.0 & 14.8 & n.d. \\
\hline $30 \mathrm{R}-4$ & 273.65 & n.d. & 32.8 & 14.5 & n.d. \\
\hline $33 R-4$ & 302.60 & n.d. & 28.9 & 14.4 & n.d. \\
\hline \multicolumn{6}{|l|}{$119-743 \mathrm{~A}-$} \\
\hline $1 \mathrm{H}-1$ & 0.94 & 490 & 50.3 & 10.6 & 10.5 \\
\hline $3 \mathrm{H}-1$ & 3.35 & 502 & 49.1 & 11.4 & 11.6 \\
\hline $9 \mathrm{H}-1$ & 41.65 & 510 & 36.8 & 20.9 & 4.4 \\
\hline
\end{tabular}

gesting that barriers to the diffusion of pore-water solutes exist above and below a zone of more porous sediments from 175 to 300 mbsf. Thus, the waxing and waning of glaciers appear to have a significant effect upon diffusional mass transfer in the underlying sediments.

Sediment compositions at Site 739 record a background supply of glacially-derived, terrestrial, siliciclastic debris with an increase in pelagic input through time. A detailed description of the stratigraphy and sediment composition for all of the Prydz Bay sites is offered by Hambrey et al. (this volume). As Figure 4 indicates, the entire sequence is carbonate poor (mean $=0.84 \%$ $\mathrm{CaCO}_{3}, \mathrm{n}=52$ ) and has an average organic carbon content of $0.6 \%(\mathrm{n}=52)$. A distinct maximum in sedimentary organic carbon occurs near 150 mbsf (maximum $=3 \%$ ).

\section{Interstitial-Water Chemistry}

Samples obtained at Site 739 indicate that sedimentary pore waters in the outer shelf region of Prydz Bay are derived from the overlying water column. Poor core recovery resulted in the collection of only one interstitial-water sample in the upper 100 $\mathrm{m}$ of sediment cored at Site 739 . We can, therefore, only infer about the biogeochemical environment of the sequence beneath the seafloor. A total of 15 water samples was squeezed from sediments cored from 27 to 465 mbsf. Results of the chemical analyses performed on these samples are displayed as concentration vs. depth plots in Figure 5. The mean chloride concentration of the pore fluids is $556 \mathrm{mM}$ (s.d. $=5 \mathrm{mM}$ ). The mean value and small variability of the chloride measurements reflect the marine character of the interstitial waters within the outer shelf sediments.

Bacterial sulfate reduction is the dominant biochemical process affecting the chemistry of the interstitial waters at Site 739. Dissolved sulfate concentrations decrease $78 \%$ within the cored interval. Most of the sulfate decrease takes place in the first 175 mbsf (Fig. 5), indicating that the organic carbon maximum near 150 mbsf (Fig. 4) may be the most active zone of bacterial sulfate reduction. The overall extent of the sulfate decrease may be viewed as anomalously small considering that the organic carbon content of the sediments exceeds $1 \%$ in some strata. However, Rock-Eval analyses of similar sediments from Site 742 indicate that a significant fraction of the organic matter at Site 739 is probably relatively unreactive type III kerogen (Barron, Larsen, et al., 1989). Thus, although organic matter is abundant in the glacial sediments, its refractory nature prevents the complete exhaustion of pore-water sulfate.

The strong anticorrelation between dissolved sulfate and ammonium concentrations $(r=-0.903, n=15)$ corroborates the primary influence of sulfate reduction on nutrient concentrations in Site 739 pore waters. Interstitial-water ammonium increases to relatively high levels (approximately $1 \mathrm{mM}$ ) in the uppermost 200 mbsf. A close relationship between sulfate reduction and ammonium production exists in a variety of marine environments (Cranston, this volume).

Pore-water alkalinities are nearly twice as large as seawater values from 175 to $263 \mathrm{mbsf}$ and decrease with depth to 445 mbsf. Sample sizes were not large enough to allow alkalinity measurements in the upper $160 \mathrm{~m}$ of the sediment column. The deep alkalinity trend implies that even higher alkalinities exist above 200 mbsf. Excess alkalinity may also be related to sulfate reduction. A positive correlation $(r=0.727, n=8)$ between dissolved calcium and alkalinity suggests that the alkalinity produced during microbial catabolism of organic matter is precipitated as calcium carbonate below 263 mbsf.

Major element analyses of the interstitial waters indicate that calcium is being released from the sediments within $30 \mathrm{~m}$ of the seafloor and that calcium, magnesium, and potassium ions are being precipitated at greater depths. The dissolved calcium concentration at 27 mbsf is nearly twice that of average seawater. Below this level, it decreases with depth before leveling off at approximately 162 mbsf (Fig. 5). Thus, a maximum exists near the seafloor in the interstitial-water calcium profile. Magnesium concentrations decrease with depth to the bottom of the cored interval (Fig. 5). Only two of the water samples were large enough to permit shore-based sodium and potassium analyses. Sodium concentrations are similar to seawater values at 263 and 397 mbsf. However, potassium concentrations at the same depths are about $75 \%$ lower than seawater concentrations. Calcium is clearly being released to the pore fluids near the seafloor. The fact that calcium concentrations do not decrease significantly below 162 mbsf suggests that it is being precipitated between 27 and 162 mbsf. Magnesium continues to decrease between the 


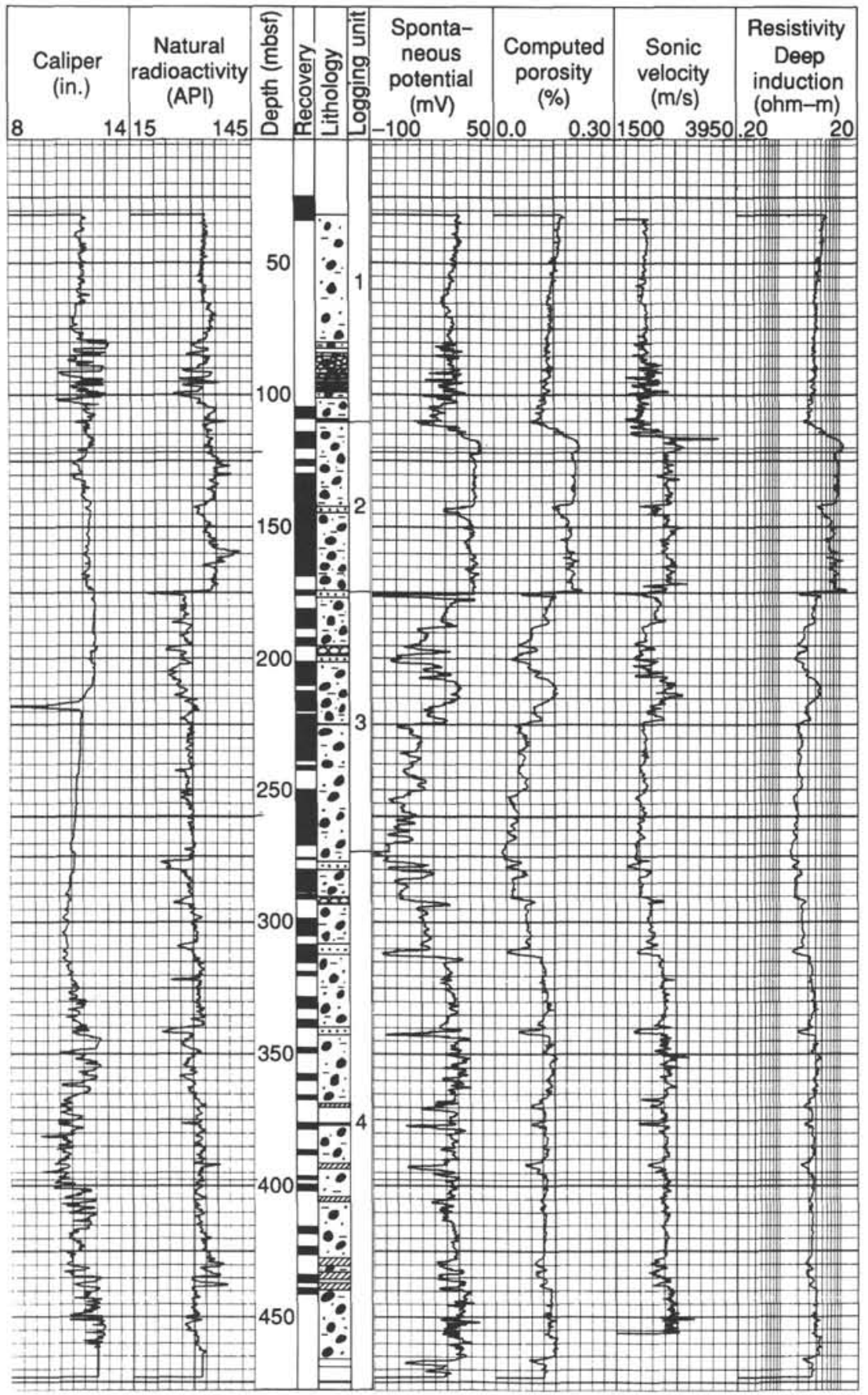

\author{
Diamictite \\ Alternation of diamictite
(sandy sediment type) \\ 㝖 Boulders or blocks \\ Sand layers \\ III) Radioactive sand layers \\ (potassium feldspar and/or zircon)
}

Figure 3. Summary stratigraphic log for Site 739 showing downhole logs, core recovery, lithology, and downhole logging units (from Barron, Larsen, et al., 1989). The lithology is based on core observations and inferences from the downhole logs.

deepest pair of samples, indicating that it is participating in reactions below 465 mbsf. The two measured potassium concentrations are nearly identical, implying that a sedimentary potassium sink exists in the upper $400 \mathrm{~m}$ of sediment.

A large maximum in the aqueous silica profile exists midway through the cored interval at Site 739. Aqueous silica concentrations climb rapidly near 150 mbsf, exceed $600 \mathrm{M}$ near the maximum, and decrease dramatically near 300 mbsf (Fig. 5). The maximum coincides with a zone of diatom-rich sediments (Hambrey et al., this volume) and is capped above and below by lowporosity sediments that provide a barrier to diffusion. The diffusion barriers exacerbate the aqueous silica maximum. The sediments below 300 mbsf are essentially barren of biogenic silica. Thus, the abrupt drop in aqueous silica near this level may simply reflect a large decrease in the diffusion rate in the deeper, more dense sediment layers.

Pore-water samples from 263 to 397 mbsf at Site 739 are only slightly depleted in ${ }^{18} \mathrm{O}$ and ${ }^{2} \mathrm{H}$ relative to samples taken near the seafloor at other Prydz Bay sites. The three samples from Site 739 have nearly identical stable isotope signatures $\left(\partial^{18} \mathrm{O}=\right.$ $\left.-0.6, \partial^{2} \mathrm{H}=-7\right)$. Weathering of unstable rock fragments and minerals derived from high-temperature igneous and metamorphic sources to low-temperature assemblages would result in the preferential removal of ${ }^{18} \mathrm{O}$ from the pore fluids. Thus, these 

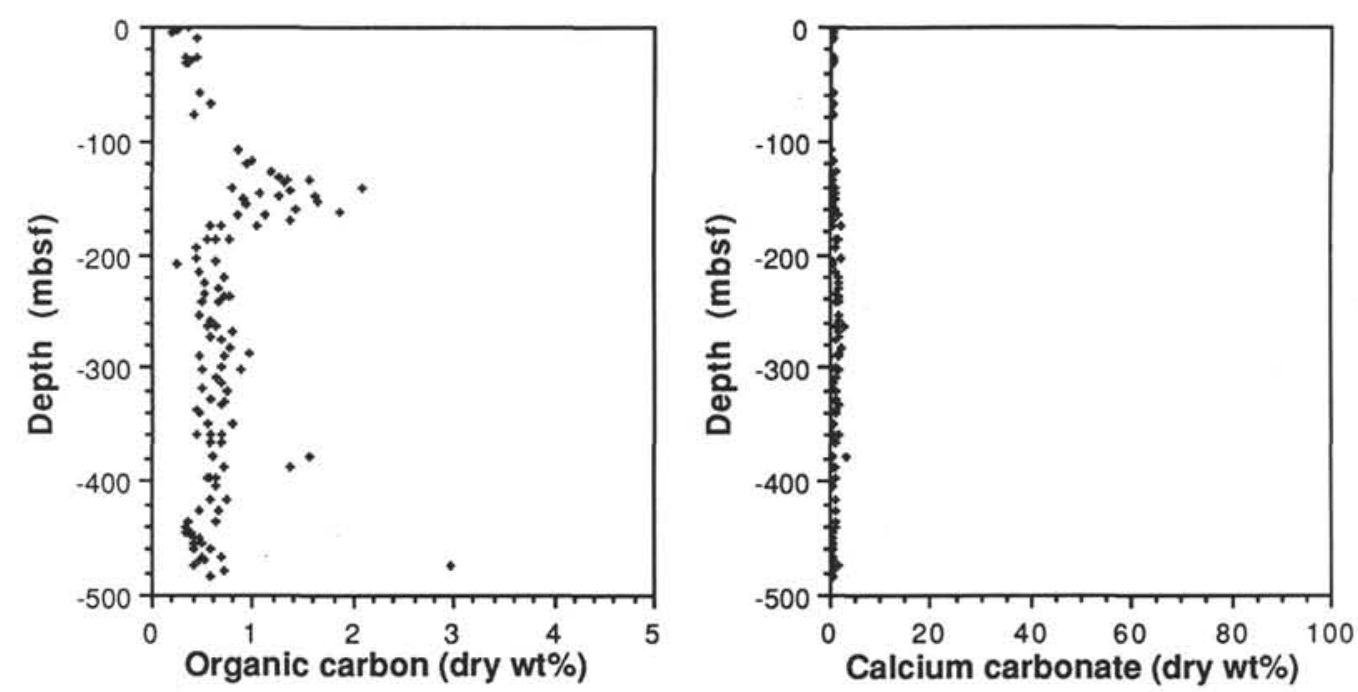

Figure 4. Organic carbon and calcium carbonate contents of Site 739 sediments. Plots incorporate data from ODP minicore samples (Table 1) and high-resolution samples (Cranston, this volume).
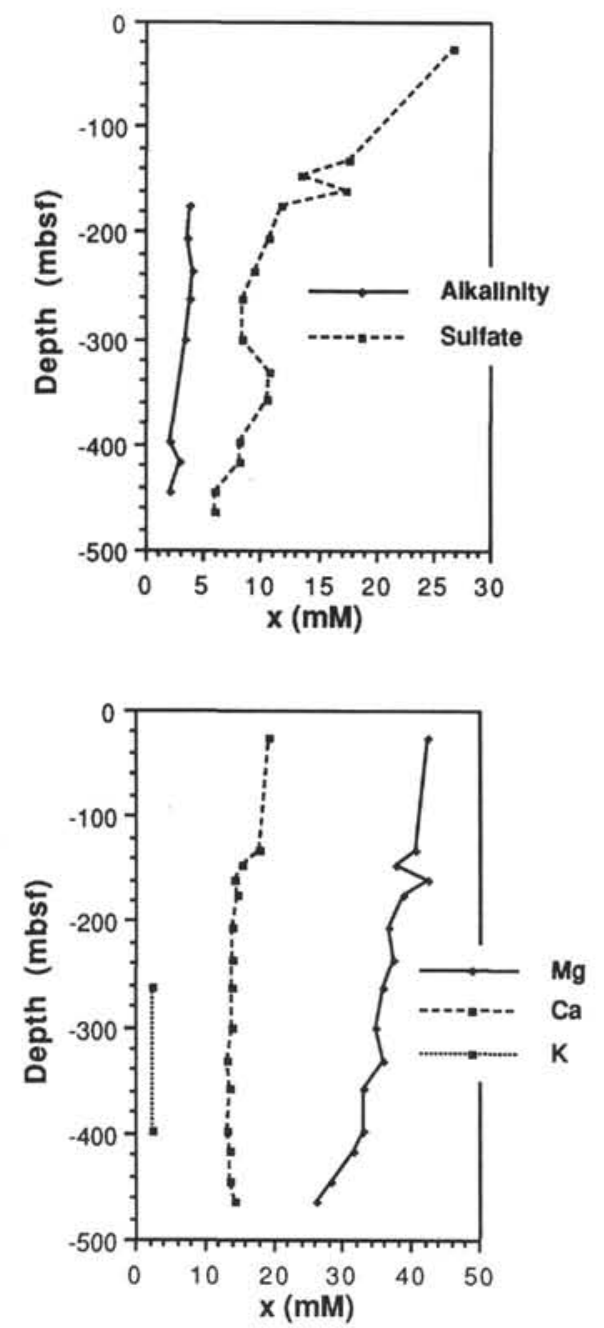
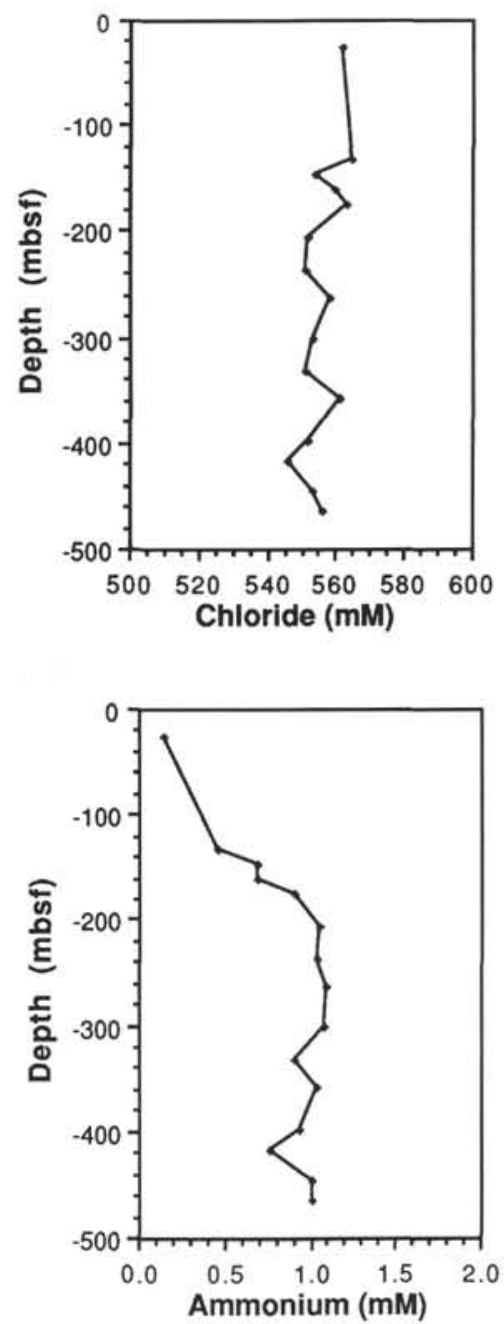
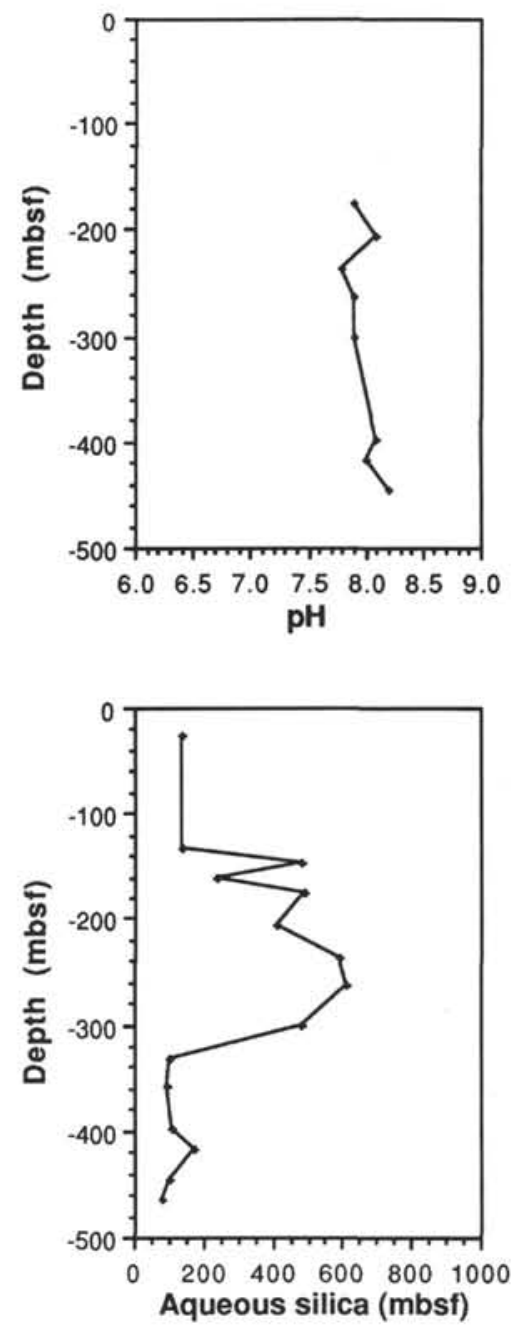

Figure 5. Interstitial-water solute distributions at Site 739. 
slightly lower $\partial^{18} \mathrm{O}$ and $\partial^{2} \mathrm{H}$ values may be due to weathering reactions.

\section{Site 740}

A sedimentary sequence consisting of marine, glacial, and terrestrial sediments was cored $30 \mathrm{~km}$ from the Antarctic coast at Site $740\left(68^{\circ} 41.22^{\prime} \mathrm{S}, 76^{\circ} 43.25^{\prime} \mathrm{E}\right.$; water depth $=807.5 \mathrm{~m}$; Fig. 1). Coring penetrated $225.5 \mathrm{~m}$ of sediment, but recovery was a scant $32 \%$. Site 740 represents the thickest sequence of terrestrial sediments yet drilled by ODP (Barron, Larsen, et al., 1989). Strata from 225.5 to 56.6 mbsf consist of greenish gray and red sandstones with interbedded siltstones and claystones. This "red bed" sequence is interpreted as a fluvial facies deposited in a warm, dry climate (Turner, this volume). Seismic-reflection surveys indicate that the sandstones are positioned $300 \mathrm{~m}$ above crystalline basement (Barron, Larsen, et al., 1989). A drilling breccia of amphibolite gneiss and intermediate igneous rocks is all that remains of the sediment cored from 56.6 to 23.2 mbsf. Drilling conditions indicated that this portion of the sequence consists of the same boulder-laden, glacial diamictites that floor much of Prydz Bay (Hambrey et al., this volume). Seafloor sediments at Site 740 are dominated by diatom ooze with minor clayey and silty layers. This thin layer of pelagic sediments contains the only significant quantity of organic matter (approximately 1.4\%) in the recovered sequence. None of the shipboard inorganic carbon analyses indicated the presence of more than $0.8 \%$ calcium carbonate (Barron, Larsen, et al., 1989).

Physical-properties measurements performed on Site 740 sediments reveal a possible barrier to solute diffusion near 16.7 mbsf. The diatom oozes near the seafloor are characterized by porosities that range from $70 \%$ to $88 \%$ and water contents that vary between $45 \%$ and $75 \%$. Below $16.7 \mathrm{mbsf}$, porosities drop to $20.0 \%-35.2 \%$ and water contents fall to $8.5 \%-17.3 \%$ (Barron, Larsen, et al., 1989). Bulk-sediment diffusion coefficients for pore-water solutes are proportional to the available porosity (Berner, 1980). Thus, diffusion rates should decrease substantially below $16.7 \mathrm{mbsf}$ at Site 740 .

\section{Interstitial-Water Chemistry}

The nine interstitial-water samples collected at Site 740 provide evidence of possible mixing between ocean waters and terrestrial ground waters. Results of the chemical analyses performed on these samples are displayed as concentration vs. depth plots in Figure 6. Pore-water chloride concentrations decrease $12 \%$ in the upper $223 \mathrm{~m}$ of the sedimentary sequence (Fig. 6). Chlorine is not known to participate in any sedimentwater reactions that could result in a substantial withdrawal of chloride from the fluid phase. In addition, pore-water salinities drop by $13 \%$ over the same depth interval at Site 740 (Table 1). Together, these data indicate that the interstitial waters are becoming more dilute with increasing depth below the seafloor.

Further evidence for the infiltration of meteoric waters into the sediments at Site 740 comes from oxygen and hydrogen isotope analyses of the pore waters. Interstitial waters near the seafloor are depleted in ${ }^{18} \mathrm{O}\left(\partial^{18} \mathrm{O}=-0.6 \%\right)$ and ${ }^{2} \mathrm{H}\left(\partial^{2} \mathrm{H}=\right.$ $-4 \%$ ) relative to SMOW. These values are very similar to the reported isotopic composition of Antarctic bottom water (Craig and Gordon, 1965; Welhan, 1987), which is isotopically lighter than most seawaters as a result of mixing with glacial meltwater. At $101 \mathrm{mbsf}$, however, the pore-water $\partial^{2} \mathrm{H}$ and $\partial^{18} \mathrm{O}$ values are $31 \% 0$ and $3 \%$ respectively, lower than the seafloor values (Fig. 7). A marine interstitial-water $\partial^{2} \mathrm{H}$ value as low as -35 has never been documented. In light of the substantial decreases in salinity and chloride concentration, the stable isotope analyses of Site $\mathbf{7 4 0}$ pore waters offer strong evidence for offshore flow of terrestrial groundwater beneath Prydz Bay.

Virtually all of the microbial activity below the sediment/ water interface at Site 740 is confined to the glacial and marine sediments in the uppermost $56.6 \mathrm{mbsf}$. The low dissolved sulfate concentrations and the strong "hydrogen sulfide" odor of the two shallowest samples attest to the anoxic conditions beneath the seafloor. Interstitial-water alkalinity $(23.19 \mathrm{mM})$, phosphate $(152 \mu \mathrm{M})$, and ammonium $(2.04 \mathrm{mM})$ at $1.45 \mathrm{mbsf}$ are the highest values measured for the entire Prydz Bay data set. Sulfate concentrations are linearly correlated with alkalinity $(r=$ $0.867, \mathrm{n}=6)$, phosphate concentrations $(\mathrm{r}=0.863, \mathrm{n}=6)$, and ammonium concentrations $(r=0.523, n=8)$, indicating that sulfate reduction is the primary process responsible for pore-water nutrient production. These data indicate that most of the organic matter presently reaching the seafloor is very reactable, marine organic matter. In addition, the surface waters nearest the Amery ice shelf appear to be more biologically productive than the outer shelf waters above Site 739 .

Sharp decreases in interstitial-water silica, alkalinity, phosphate, and ammonium within the first $61 \mathrm{mbsf}$ indicate that the highly compacted glacial sediments present an effective barrier to the diffusion of solutes from the diatom oozes above to the terrestrial sandstones below (Fig. 6). All of these solutes are being released to the interstitial waters within the diatom oozes. The decrease in concentration with depth may be much more abrupt than Figure 6 indicates; poor core recovery precluded sampling of the contact between the diatom oozes and the underlying diamictons. It is clear from the concentration vs. depth profiles, however, that the chemical composition of the pore waters below $60 \mathrm{mbsf}$ is much different than that of the pore waters above $17 \mathrm{mbsf}$. The low permeability of the glacial sediments $(<0.036 \mathrm{~m} / \mathrm{yr}$; Solheim et al., this volume) is undoubtedly partially responsible for the presence of relatively low-salinity $(32.5 \mathrm{~g} / \mathrm{kg})$ waters at the shallow depth of $61 \mathrm{mbsf}$.

Dissolved major cations also exhibit large concentration-vs.depth gradients at Site 740 (Fig. 6). Between 17 and 101 mbsf, interstitial-water sodium, magnesium, and potassium concentrations decrease by $115,27.5$, and $8.3 \mathrm{mM}$, respectively. Within the same depth interval, dissolved calcium concentrations increase by $46.8 \mathrm{mM}$. Charge balance is maintained in the pore waters by decreases in alkalinity, chloride, and sulfate concentrations. The combined downward diffusion of cations and anions may be an indication of charge coupling.

\section{Site 741}

Site $741\left(68^{\circ} 23.16^{\prime} \mathrm{S}, 76^{\circ} 23.02^{\prime} \mathrm{E}\right.$, water depth $\left.=551.4 \mathrm{~m}\right)$ is positioned $36 \mathrm{~km}$ northwest of Site 740 and approximately 70 $\mathrm{km}$ from the Antarctic coast (Fig. 1). Sites 740 and 741 are similar in that both have experienced marine, glacial, and terrestrial environments. Only $26 \%$ of the $128.1 \mathrm{~m}$ of sediment cored at Site 741 is available for study as a result of to the difficult drilling conditions. The uppermost $4.1 \mathrm{~m}$ of sediment consists of diatom ooze that grades downward into glacially deposited silty clays. The sequence from 4.1 to $24.05 \mathrm{mbsf}$ is thought to consist of boulder-rich diamicton; fragments of gneiss are all that was recovered from this interval. Terrestrial gray sandstones and siltstones of Early Cretaceous(?) age comprise the remainder of the section extending to $128.1 \mathrm{mbsf}$. Carbonized plant fragments (coal) are scattered throughout the lowermost unit. All but 4 of the 22 shipboard analyses for inorganic carbon revealed calcium carbonate contents of less than $1 \%$ in the sediments (Barron, Larsen, et al., 1989). Seismic stratigraphy indicates that the terrestrial sediments at Site 741 occupy a stratigraphic position 

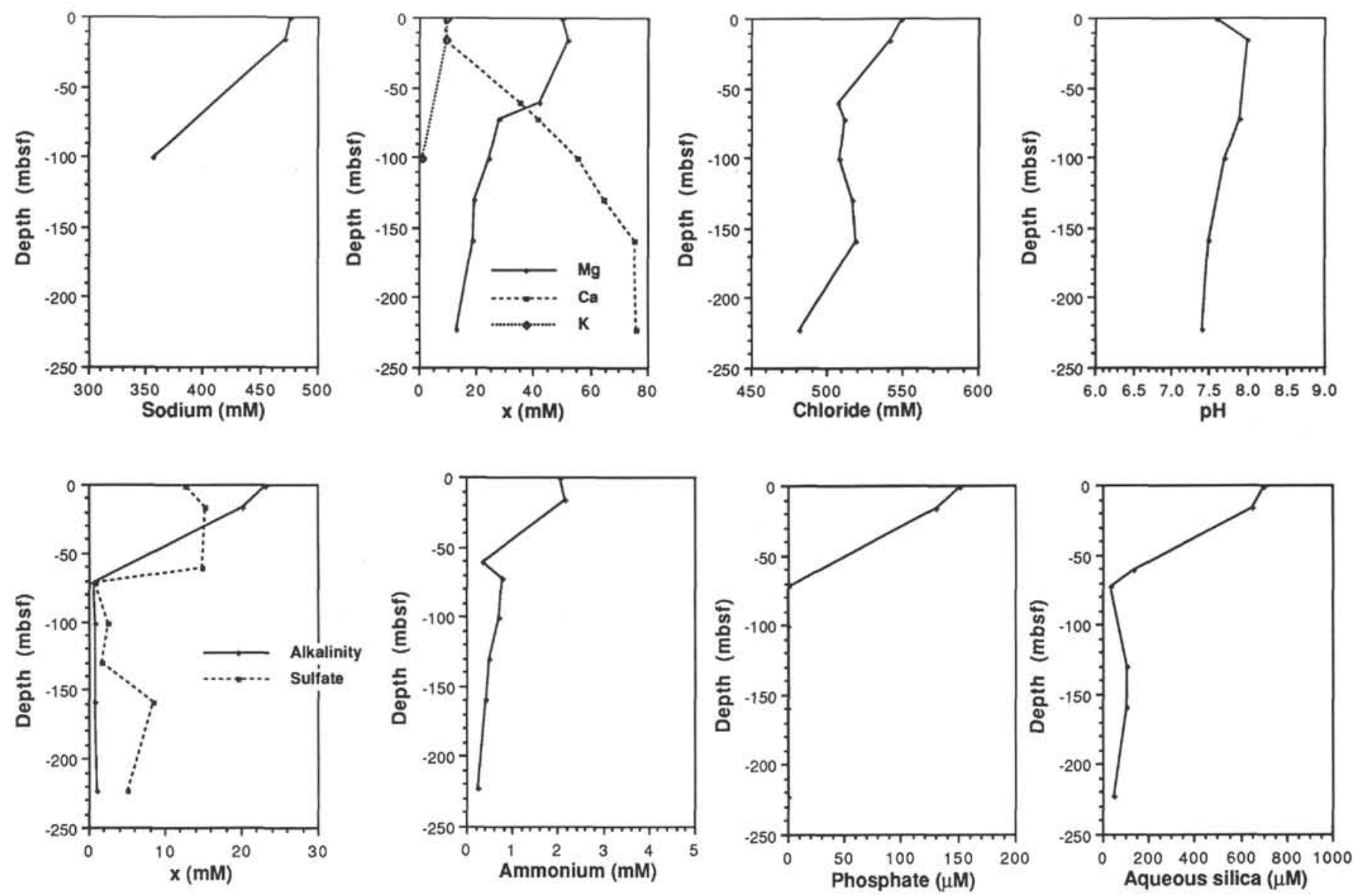

Figure 6. Interstitial-water solute distributions at Site 740 .

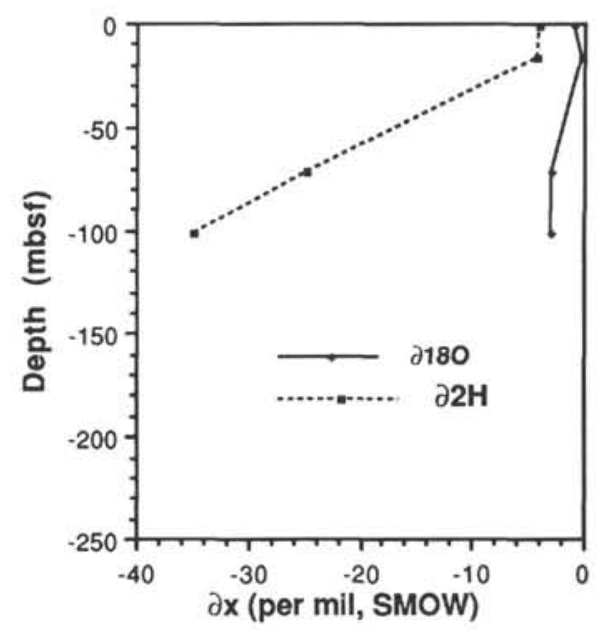

Figure 7. Depth variations of oxygen and hydrogen isotope ratios in Site 740 interstitial waters.

$1500 \mathrm{~m}$ above the red bed sequence cored at Site 740 (Barron, Larsen, et al., 1989).

\section{Interstitial-Water Chemistry}

The low water content of the terrestrial sediments cored at Site 741 limited pore-water collection to three samples. Of the three, only one sample was large enough to permit the full complement of analyses. Identification of reaction zones is nearly impossible with such a small data set, but the analytical results do indicate the existence of interstitial-water concentration gradients. The two deepest pore-water samples were extracted from the terrestrial sediments. The salinity and chloride concentration drop $3.7 \%$ and $2.7 \%$, respectively, between these two samples. Although it is possible that these decreases indicate the incursion of terrestrial ground waters into the sedimentary sequence at a deeper level, the composition of both samples is well within the range of typical marine pore fluids.

Nutrient analyses of Site 741 pore waters indicate that bacterial activity below the sediment/water interface in Prydz Bay tends to decrease in the seaward direction. Dissolved sulfate concentrations decrease $29 \%$ between 3 and $115 \mathrm{mbsf}$ at Site 741 (Table 2). Interstitial-water phosphate at $3 \mathrm{mbsf}$ is elevated relative to seawater and dissolved ammonium concentrations increase slightly with increasing depth. The pore-water sulfate gradient is much lower at Site 741 than at Site 740 . This suggests that the flux of organic matter into the sediments is higher in the deeper waters encountered closer to the shoreline (Fig. 2). Most of the bacterial activity at Site 740 is concentrated in the seafloor diatom oozes that represent recent sedimentation. Thus, the very general trend toward smaller dissolved sulfate gradients and nutrient concentrations in the seaward direction may be an indication of higher surface-water productivity near the shoreline.

Aqueous silica concentrations decrease sharply below the contact between glaciomarine and terrestrial sediments at Site 741. The relatively high abundance of aqueous silica at $3 \mathrm{mbsf}$ is due to the dissolution of biogenic silica. Lower silica concentrations in the deeper interstitial-water samples indicate that 
highly soluble silicates are lacking in the terrestrial sediments. Considering the large decrease in porosity and water content with depth at Site 741, much of the aqueous silica in the diatomaceous sediments probably diffuses upward into the overlying water column.

The gradients of dissolved major cations at Site 741 are much smaller than those measured at Site 740. Dissolved magnesium concentrations decrease $26 \%$ while pore-water calcium increases $57 \%$ within the depth range sampled at Site 741 . The sodium and potassium data sets consist of a single sample, precluding measurement of depth gradients for these elements. The interstitial water magnesium and calcium concentration vs. depth gradients are factors of two and nine times greater, respectively, at Site 740 than at Site 741 (Table 3).

\section{Site 742}

Located $60 \mathrm{~km}$ from the shelf break, Site $742\left(67^{\circ} 32.98^{\prime} \mathrm{S}\right.$, $75^{\circ} 24.27^{\prime} \mathrm{E}$, water depth $=415.7 \mathrm{~m}$ ) has experienced a glacial history similar to Site 739 , which lies $30 \mathrm{~km}$ to the northwest (Figs. 1 and 2). A glacial sequence primarily composed of diamictite was cored to a total depth of 316 mbsf at Site 742. Core recovery $(53 \%)$ was better than at any of the other Prydz Bay sites. Soft, diatomaceous, glacial sediments comprise the seafloor at Site 742 .

The diamictites below 5.4 mbsf are much firmer and exhibit variations in physical properties that are a result of the movement of glaciers across the continental shelf (Barron, Larsen, et al., 1989; Solheim et al., this volume). The diamictites cored at Site 742 are similar to those cored at Site 739 in that sharp variations in physical properties occur throughout the sedimentary sequence. These variations are revealed in the resistivity log shown in Figure 8. As was mentioned previously, wet-sediment electrical resistivity can be used as a relative measure of the ease with which ions diffuse through the sediment column. Sharp increases in resistivity occur at 135 and 195 mbsf at Site 742 (Fig. 8). These zones represent barriers to the downward diffusion of pore-water solutes. Packages of anomalously low resistivity sediments occur from 114 to 136 mbsf and from 173 to 195 mbsf (Fig. 6). These sediments have higher porosities $(31.9 \%-39.5 \%)$ and water contents $(15.4 \%-20.5 \%)$ than the sediments above (porosity $=25.4 \%-26.5 \%$, water content $=11.9 \%-12.2 \%$ ) and below (porosity $=25.4 \%-27.4 \%$, water content $=11.9 \%$ $12.6 \%$ ). A decrease in the mean grain size also occurs in the high porosity zones and is thought to be related to deposition in a more distal glacial regime (Solheim et al., this volume). Thus, variations in sediment lithology and consolidation related to glacial advance and retreat present a long and winding diffusion path for pore-water solutes at Site $\mathbf{7 4 2}$.

Compositional trends in the sediments deposited at Site 742 also exhibit marked similarities to those at Site 739 (Hambrey et al., this volume). Massive diamictite is the principle sediment type. The clay fraction generally comprises $20 \%-30 \%$ of the diamictites, but increases to about $50 \%$ within the low-resistivity layer mentioned previously (Hambrey et al., this volume). The mean organic carbon content of the cored sequence is $0.6 \%$ $(n=43)$, but increases to values above $1 \%$ in a maximum centered near 150 mbsf. Most of the organic matter consists of reworked type III (terrestrial) kerogen (Barron, Larsen, et al., 1989). The mean calcium carbonate content is $0.55 \%(n=72)$, although detrital carbonate and carbonate cements have been observed in the sediments below 173 mbsf (Barron, Larsen, et al., 1989). Biogenic silica is largely confined to the uppermost $20 \mathrm{~m}$ of the sediment column.

\section{Interstitial-Water Chemistry}

Chemical studies of the interstitial waters retrieved from Site 742 reveal a reactive sediment column deposited in a marine environment. Pore waters were liberated from 11 sediment samples with in-situ depths of 3-303 mbsf. The interstitial-water chemical data are displayed in concentration vs. depth profiles in Figure 9. Dissolved chloride concentrations exhibit a great deal of variability but do not change significantly between the seafloor and 303 mbsf $($ mean $=550 \mathrm{mM}$, s.d. $=8, \mathrm{n}=11)$. Nearly al of the other chemical parameters measured in the interstitial waters are correlated with sub-bottom depth.

Bacteria are active throughout the sediment column sampled at Site 742 . Peak alkalinity $(4.74 \mathrm{mM})$ and phosphate concentrations $(19 \mu \mathrm{M})$ occur near the sediment/water interface (Fig. 9). Early release of phosphate during aerobic catabolism of organic matter is favored by the labile nature of functional groups containing phosphorous (Sholkovitz, 1973). Most of the decrease in dissolved sulfate occurs below $58 \mathrm{mbsf}$ (Fig. 9). Porewater ammonium and sulfate are anti-correlated $(\mathrm{r}=-0.875$, $\mathrm{n}=9$ ) from 3 to $245 \mathrm{mbsf}$, indicating that ammonium production is related to sulfate reduction. The presence of large ammonium and sulfate gradients near the bottom of Hole $742 \mathrm{~A}$ suggests that sulfate reduction is an active process below 300 mbsf.

Dissolved major cations display strong concentration vs. depth gradients at Site 742. A maximum in the interstitial-water calcium profile (Fig. 9) near 90 mbsf indicates that calcium ions are being released from the sediments. Pore-water alkalinity decreases as calcium concentrations increase from 3 to $90 \mathrm{mbsf}$ and both trends are reversed between 90 and 303 mbsf, suggesting that these concentration gradients are linked. Magnesium and potassium concentrations decrease with depth below the seafloor (Fig. 9).

Dissolution of biogenic silica near the seafloor is the primary source of aqueous silica in the shallowest sediments sampled at Site 742. The sharp drop in aqueous silica concentration between 15 and 58 mbsf reflects the decrease in diffusion rate upon entering more consolidated glacial sediments (Fig. 9). Two small peaks in the aqueous silica concentration vs. depth profile at 116 and 174 mbsf occur near the upper boundaries of the two low-resistivity zones mentioned previously (Figs. 8 and 9).

Stable isotope analyses of Site 742 indicate that both ${ }^{2} \mathrm{H}$ and ${ }^{18} \mathrm{O}$ are being withdrawn from the interstitial waters below the sediment/water interface (Fig. 10). Pore-water $\partial^{2} \mathrm{H}$ and $\partial^{18} \mathrm{O}$ values decrease $4 \%_{0}$ and $1.2 \%$, respectively, between 3 and 116 mbsf (Table 4). A slight decrease in salinity accompanies these isotopic trends, but chloride concentrations are variable and do not indicate a definite depth gradient. Thus, there is no clear evidence for the incursion of meteoric waters into the sediments sampled at Site 742 . The stable isotope data will be interpreted in the discussion section of this report.

\section{Site 743}

Site $743\left(66^{\circ} 54.99^{\prime} \mathrm{S}, 74^{\circ} 41.42^{\prime} \mathrm{E}\right.$, water depth $\left.=988.7 \mathrm{~m}\right)$ is located on the upper continental slope. Only $22 \%$ of the 98.1 $\mathrm{m}$ of sediment cored at this site was recovered. Moderately wellsorted sand mixed with diatom ooze comprises the seafloor at Site 743 . The interval from 0.46 to $15.8 \mathrm{mbsf}$ consists of clayey silts with interbedded gravel and sand layers. A poorly recovered sequence of diamictons completes the cored sequence. The mean organic carbon and calcium carbonate contents of these sediments are $0.33 \%$ (s.d. $=0.11, \mathrm{n}=10$ ) and $0.49 \%$ (s.d. $=$ $0.90, \mathrm{n}=25$ ), respectively.

\section{Interstitial-Water Chemistry}

Poor core recovery in the diamicton sequence resulted in the collection of only three interstitial-water samples between 1 and $42 \mathrm{mbsf}$ at Site 743. Salinity and chloride concentrations of the pore-fluid samples indicates that they are normal marine waters with no input from terrestrial groundwaters (Table 1).

Site 743 confirms that anaerobic bacteria are active below the sediment/water interface along the entire Leg 119 transect of Prydz Bay. Dissolved sulfate concentrations decrease $26 \%$ 


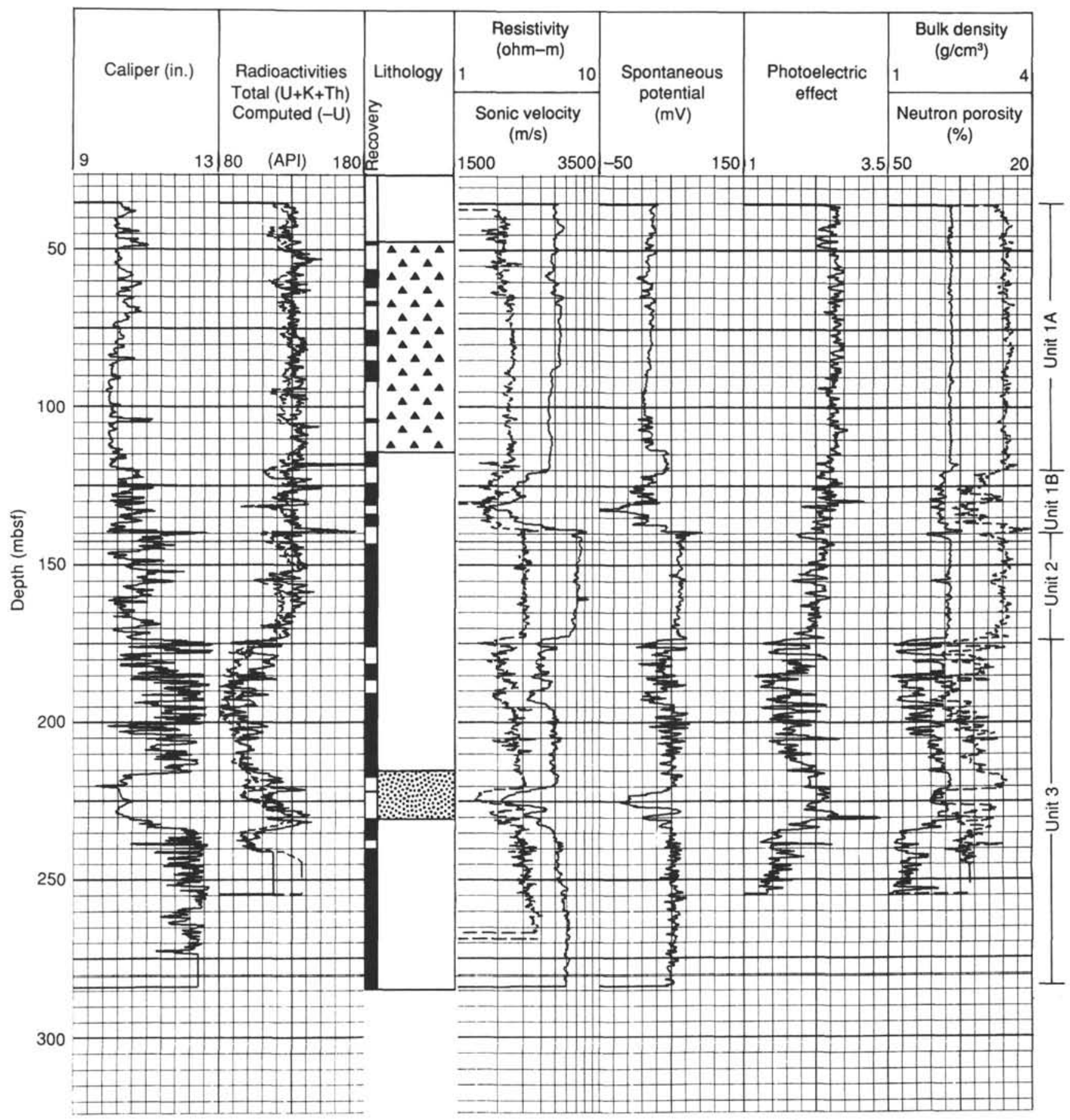

Figure 8. Summary stratigraphic log for Site 742 showing downhole logs, core recovery, and inferred lithology (diamictites and sands; from Barron, Larsen, et al., 1989).

between 1 and 42 mbsf at Site 743. Ammonium concentrations increase with depth while phosphate appears to be concentrated in the shallower pore fluids. High interstitial water sulfate concentrations indicate that sediments near the seafloor are aerobic. Degradation of the most reactive organic matter fraction by aerobic bacteria near the seafloor results in the relatively gradual approach to anaerobic conditions with increasing depth.

Interstitial-water magnesium and calcium depth trends at Site 743 are similar to those discovered at the other Prydz Bay sites. Dissolved magnesium concentrations decrease $27 \%$ and dissolved calcium concentrations increase $97 \%$ with increasing depth between 1 and 42 mbsf. As the calcium and magnesium gradients are persistent to $98 \mathrm{mbsf}$, the reaction zone that is responsible for the diffusion gradient may not have been sampled during Leg 119. Interstitial-water silica concentrations are variable and elevated well above seawater concentrations in Hole $743 \mathrm{~A}$. The average silicate concentration of the samples is 439 $\mu \mathrm{M}$ with a standard deviation of $71 \mu \mathrm{M}$. These concentrations are approximately 10 times greater than surface seawater near this site and are the result of biogenic silica dissolution in the sediments.

Site 743 interstitial waters are enriched in ${ }^{18} \mathrm{O}$ and ${ }^{2} \mathrm{H}$ relative to pore waters on the continental shelf. The higher $\partial^{18} \mathrm{O}$ and $\partial^{2} \mathrm{H}$ values encountered on the upper slope suggest that glacial 

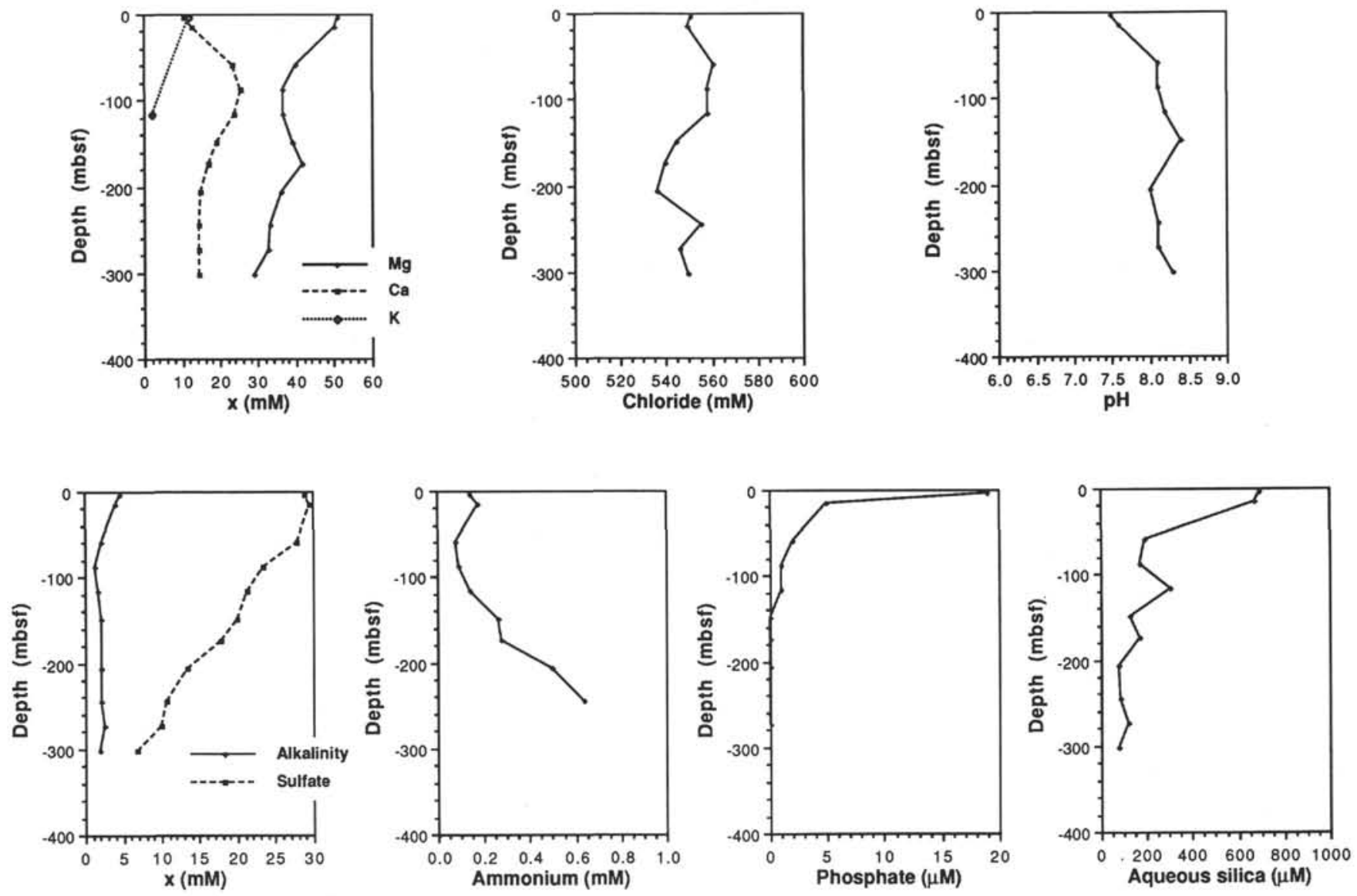

Figure 9. Interstitial-water solute distributions at Site $\mathbf{7 4 2 .}$

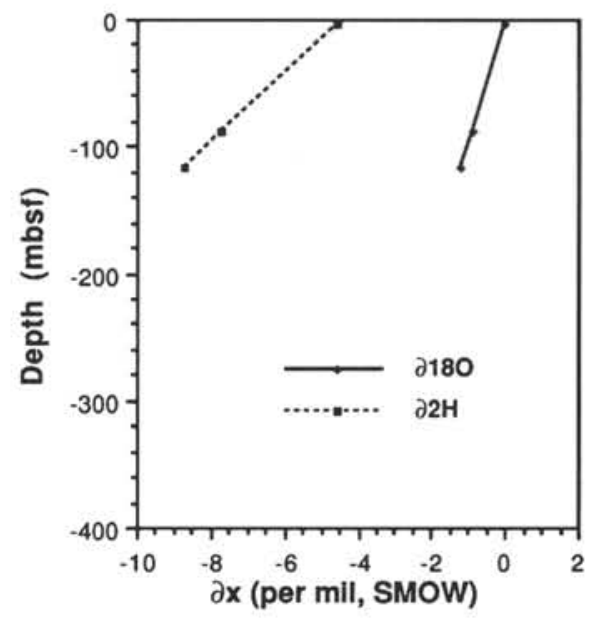

Figure 10. Depth variations of oxygen and hydrogen isotope ratios in Site 742 interstitial waters.

meltwaters are largely continued to seawater on the continental shelf.

\section{DISCUSSION AND CONCLUSIONS}

\section{Diffusion of Solutes in Glacial Sediments}

Highly consolidated glacial sediments provide an effective barrier to the vertical diffusion of interstitial-water solutes. The dependence of the diffusive flux of ions in interstitial waters on porosity and electrical resistivity can be derived from Fick's first law of diffusion:

$$
\begin{gathered}
\mathrm{J}_{\mathrm{s}, \mathrm{i}}=\phi \mathrm{D}_{\mathrm{s}, \mathrm{i}}\left(\partial \mathrm{C}_{\mathrm{i}} / \partial \mathrm{z}\right) \\
\mathrm{D}_{\mathrm{s}, \mathrm{i}}=\mathrm{D}_{\mathrm{w}, \mathrm{i}} /(\phi \mathrm{F}) \\
\mathrm{F}=\mathrm{R}_{\mathrm{b}} / \mathrm{R}_{\mathrm{w}}
\end{gathered}
$$

where $\mathrm{J}_{\mathrm{s}, \mathrm{i}}$ is the flux of solute $\mathrm{i}$ through the sediment-pore water system $\left(\mathrm{g} / \mathrm{cm}^{2} / \mathrm{s}\right), \mathrm{D}_{\mathrm{s}, \mathrm{i}}$ is the bulk sediment diffusion coefficient of solute $\mathrm{i}\left(\mathrm{cm}^{2} / \mathrm{s}\right), \mathrm{C}_{\mathrm{i}}$ is the concentration of species $\mathrm{i}$ in the interstitial water $\left(\mathrm{g} / \mathrm{cm}^{3}\right)$, and $\mathrm{z}$ is the distance in centimeters below the seafloor (positive downward), $\mathrm{D}_{\mathrm{w}, \mathrm{i}}$ is the diffusion coefficient of solute $i$ in water $\left(\mathrm{cm}^{2} / \mathrm{s}\right), \phi$ is porosity, $F$ is a number known as the formation factor, $R_{b}$ is the electrical resistivity of the sediment-pore water system, and $R_{w}$ is the electrical resistivity of the pore water (Berner, 1980). These equations indicate that highly compacted glacial sediments with high electrical resistivities and low porosities represent barriers to the diffusion of pore water solutes.

Physical evidence for the inhibition of solute diffusion rates comes primarily from the concentration vs. depth profiles of aqueous silica at Sites 739 and 742 . Biogenic silica is very soluble in the presence of most marine waters. At Site 739, a sequence of diatomaceous sediments with relatively high porosity is bounded above and below by low-porosity layers. A greatly accentuated silica maximum in the more porous sediments attests to the inability' of diffusive transport to smooth out this chemical anomaly. Smaller silica maxima were also measured in 
Table 4. Interstitial-water oxygen and hydrogen isotope ratios for Leg 119 Prydz Bay sites. Delta values are relative to the V-SMOW standard.

\begin{tabular}{|c|c|c|c|}
\hline $\begin{array}{c}\text { Sample } \\
\text { (core, section) }\end{array}$ & $\begin{array}{l}\text { Depth } \\
\text { (mbsf) }\end{array}$ & $\begin{array}{l}\delta^{18} \mathrm{O} \\
(\% 0)\end{array}$ & $\begin{array}{c}\delta \mathrm{D} \\
(\% 0)\end{array}$ \\
\hline \multicolumn{4}{|l|}{$119-739 \mathrm{C}-$} \\
\hline $\begin{array}{l}34 \mathrm{R}-2 \\
38 \mathrm{R}-2 \\
48 \mathrm{R}-1\end{array}$ & $\begin{array}{l}263.30 \\
301.80 \\
397.00\end{array}$ & $\begin{array}{l}-0.6 \\
-0.6 \\
-0.6\end{array}$ & $\begin{array}{l}-7 \\
-7 \\
-6\end{array}$ \\
\hline \multicolumn{4}{|l|}{$119-740 \mathrm{~A}-$} \\
\hline $\begin{array}{l}3 R-2 \\
11 R-1 \\
17 R-1\end{array}$ & $\begin{array}{r}16.65 \\
72.30 \\
101.30\end{array}$ & $\begin{array}{l}-0.3 \\
-3.0 \\
-3.0\end{array}$ & $\begin{array}{r}-4 \\
-25 \\
-35\end{array}$ \\
\hline \multicolumn{4}{|l|}{ 119-740B- } \\
\hline 1R-1 & 1.45 & -0.9 & -4 \\
\hline \multicolumn{4}{|l|}{$119-741 \mathrm{~A}-$} \\
\hline 1R-2 & 2.95 & n.d. & -4 \\
\hline \multicolumn{4}{|l|}{$119-742 \mathrm{~A}-$} \\
\hline $\begin{array}{l}1 \mathrm{R}-2 \\
11 \mathrm{R}-2 \\
14 \mathrm{R}-2\end{array}$ & $\begin{array}{r}2.95 \\
87.30 \\
116.20\end{array}$ & $\begin{array}{l}-0.0 \\
-0.9 \\
-1.2\end{array}$ & $\begin{array}{l}-5 \\
-8 \\
-9\end{array}$ \\
\hline \multicolumn{4}{|l|}{$119-743 \mathrm{~A}-$} \\
\hline $\begin{array}{l}1 \mathrm{H}-1 \\
3 \mathrm{H}-1 \\
9 \mathrm{H}-1\end{array}$ & $\begin{array}{r}0.94 \\
3.35 \\
41.65\end{array}$ & $\begin{array}{l}+0.2 \\
+0.1 \\
+0.2\end{array}$ & $\begin{array}{r}-2 \\
0 \\
+1\end{array}$ \\
\hline
\end{tabular}

the pore waters of diamictites with higher porosities at Site 742 . Variations in the porosity of glacial sediments at Sites 739 and 742 are apparently related to changes in lithology and grain size that are a function of depositional area's distance from the edge of the ice sheet. Thus, glacial cycles clearly have an impact on the geochemistry of sediments that are periodically overlain by great expanses of ice.

\section{Incursion of Meteoric Waters}

Groundwater from the Antarctic continent appears to be flowing into Prydz Bay sediments through the sequence of terrestrial sediments that lie underneath the glacial sediments. Pore waters extracted from the fluvial sediments cored at Site 740 have much lower $\partial^{2} \mathrm{H}$ values $(-35 \%)$ than typical marine pore fluids. A $12 \%$ downhole decrease in chloride concentrations accompanies the large deuterium depletion. Together, these interstitial-water chemical shifts provide strong evidence for the incursion of meteoric waters into the sedimentary sequence sampled at Site 740 . None of the other Prydz Bay sites appear to be affected by terrestrial waters. The failure of continental groundwater to impact other sites and the strong seaward dip of the red bed sequence cored at Site 740 (Fig. 2) indicate that the meteoric waters are sequestered in the terrestrial sandstones and siltstones by permeability and diffusional barriers presented by shallower sediments.

\section{Glacial Constraints on the Organic Matter Content of Prydz Bay Sediments}

The periodic movement of glaciers across the continental shelf of East Antarctica has also affected the biogeochemistry of the sediments deposited there. Glacial advances have deposited large amounts of terrestrial organic material in Prydz Bay.
Shipboard Rock-Eval analyses of the glacial sequences generally indicated the presence of relatively unreactive type III kerogen. Significant amounts of marine organic matter can accumulate only when the ice has retreated from the area of deposition. Large-scale glacial advances may erode much of the pelagic material and redeposit it on the continental slope. Marine organic mater is much more reactive in the sedimentary environment than terrestrial organic matter. Evidence for this can be found at Site 740. A thin layer of diatom ooze caps the sedimentary sequence at this site. This appears to be the largest accumulation of biogenic debris resting on the seafloor along the Leg 119 transect of Prydz Bay. It is also the most reducing package of sediment sampled during our voyage. Interstitial-water sulfate and nutrient gradients at Site 740 are much larger than those that exist in the thick piles of diamict sediments on the outer shelf. Thus, the large amounts of erosion associated with glacial advances appears to have had the effect of limiting the amount of marine organic matter that is incorporated into the sediments on the continental shelf.

\section{An Alkalinity Model}

Notwithstanding the fact that most of the organic matter trapped in Prydz Bay sediments has a terrestrial origin, bacterial sulfate reduction occurs below the sediment/water interface at each of the five ODP sites. The sulfate depletions measured at each of the five sites indicate that enough reactable organic matter is present in the sediments to allow bacteria to consume all of the available oxygen, nitrate, manganese, and iron in catabolic reactions. Microbial sulfate reduction is a strictly anaerobic process that uses sulfate anions as electron receptors during the catabolism of organic material. Phosphate, ammonium, and bicarbonate icons are released to the interstitial waters with the following stoichiometry:

$$
\begin{gathered}
\left(\mathrm{CH}_{2} \mathrm{O}\right)_{106}\left(\mathrm{NH}_{3}\right)_{16} \mathrm{H}_{3} \mathrm{PO}_{4}+53 \mathrm{SO}_{4}^{2-}+39 \mathrm{H}_{2} \mathrm{O} \rightarrow \\
106 \mathrm{HCO}_{3}^{-}+53 \mathrm{HS}^{-}+16 \mathrm{NH}_{4}^{+}+\mathrm{HPO}_{4}^{2-}+39 \mathrm{H}_{3} \mathrm{O}^{+} .
\end{gathered}
$$

The in-situ stoichiometry of the reaction is dependent upon the composition of the available organic matter.

Equation 4 indicates that sulfate reduction affects the alkalinity of interstitial waters by producing proton receptors that are effective in the $\mathrm{pH}$ range of most marine sediments. A simple model can be constructed in which the alkalinity of a pore fluid is a function of the sulfate reduction stoichiometry and the dissolution of calcium carbonate in the sediments (Sholkovitz, 1973):

$$
\begin{aligned}
(\text { alkalinity })_{\mathrm{d}}= & (\text { alkalinity })_{\mathrm{i}}-2 \Delta\left[\mathrm{SO}_{4}^{2-}\right] \\
& +\Delta\left[\mathrm{NH}_{4}{ }^{+}\right]+2 \Delta\left[\mathrm{Ca}^{2+}\right]
\end{aligned}
$$

where alkalinity $y_{d}$ is the alkalinity at any depth below the seafloor and alkalinity $y_{i}$ is the alkalinity at the sediment/water interface. This model was used to calculate alkalinity as a function of depth at each of the Prydz Bay coring sites. The results of the alkalinity model calculations are compared to the measured titration alkalinities in Figure 11. At each site, the measured alkalinities are much lower than the alkalinities predicted by sulfate depletions and calcium increases in the interstitial waters.

The alkalinity model suggests that the calcium ion gradients in Prydz Bay interstitial waters are not a result of carbonate dissolution. When the carbonate dissolution component $\left(2 \Delta\left[\mathrm{Ca}^{2+}\right]\right)$ is removed from the model the calculated alkalinities are still as much as an order of magnitude greater than the measured values (Fig. 11). Thus, most of the alkalinity produces during microbial sulfate reduction is removed from the pore waters of Prydz Bay sediments. 


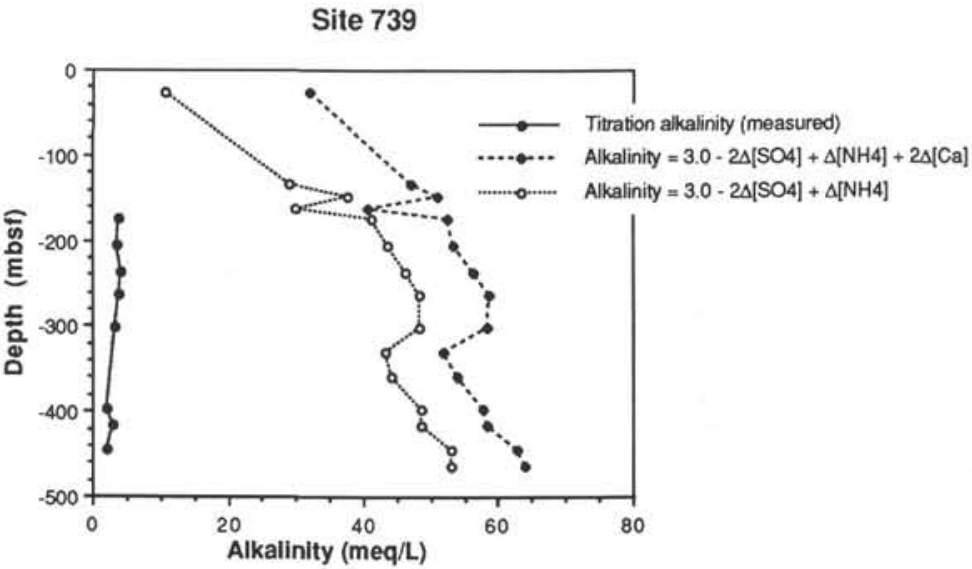

Site 740

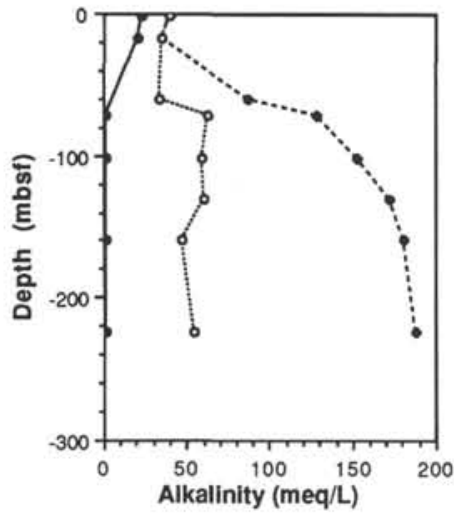

Site 741

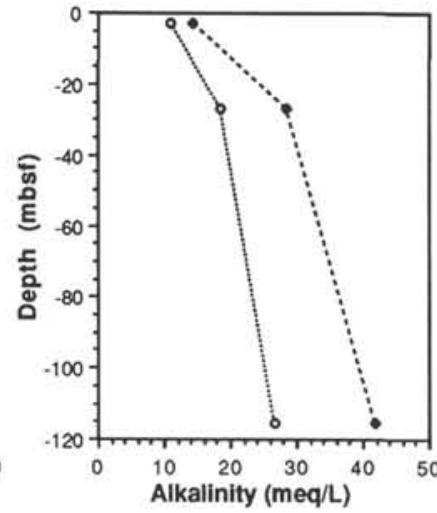

Site 742

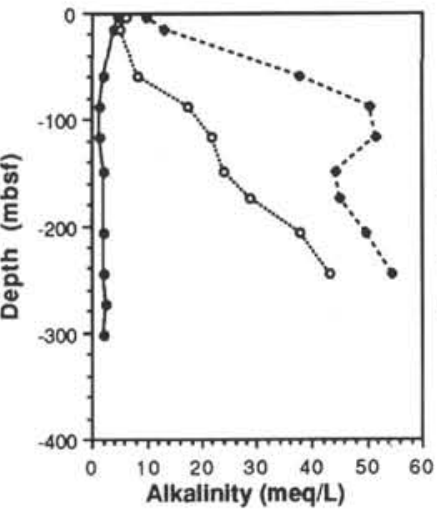

Site 743

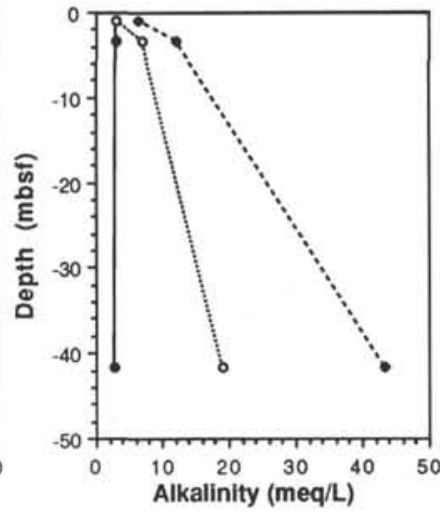

Figure 11. Comparisons between alkalinities predicted from a simple model and the measured titration alkalinities at each of the ODP Leg 119 Prydz Bay sites. The models calculate the alkalinity at a given depth as a function of the release of bicarbonate ions and ammonia during sulfate reduction and the release of carbonate ions as a result of calcium carbonate dissolution (Sholkovitz, 1973). The legend applies to each of the plots. Refer to the text for an explanation of the results.

\section{Thermodynamic Modeling of Carbonate Equilibria}

The two most probable means of reducing pore-water alkalinity are diffusion of proton receptors (for example, $\mathrm{HCO}_{3}^{-}$, $\mathrm{NH}_{3}, \mathrm{HPO}_{4}^{2-}$ ) into the overlying water column and precipitation of carbonates. While upward diffusion is a distinct possibility, it cannot be evaluated from these data sets because there is no information on the chemical gradients between the shallowest sediments and the ocean bottom waters. The probability of carbonate precipitation can, however, be determined by means of thermodynamic calculations.

The saturation states of the Prydz Bay pore fluids with respect to calcite and aragonite were calculated using two different methods. Carbon dioxide speciation and calcium carbonate solubility in aqueous electrolyte solutions are functions of the temperature and pressure of the system and the ionic strength of the aqueous phase. The solubility of calcium carbonates increases with decreasing temperature and increasing pressure and ionic strength. The effect of ionic strength on carbonate solubility is a function of the tendency of aqueous carbonate species to form complexes and ion pairs with dissolved cations. The saturation state of the Prydz Bay interstitial waters were evaluated by calculations of mineral saturation indices, $\Omega$ :

$$
\Omega=\left(\left[\mathrm{Ca}^{2+}\right]\left[\mathrm{CO}_{3}^{2-}\right]\right) \div \mathrm{K}_{\mathrm{sp}},
$$

where the numerator is the activity product of calcium and carbonate ions in the pore fluid and the denominator is the solubility product of the specified mineral.

Saturation indices for aragonite and calcite were calculated at the estimated in-situ values of temperature and pressure for interstitial-water samples from each of the Prydz Bay coring sites using the apparent dissociation constants and solubility products given by Gieskes (1974). The calculation results are plotted as a function of depth below the sediment/water interface in Figure 12. In-situ temperature measurements were not made during the Prydz Bay phase of ODP Leg 119. Therefore, temperatures were estimated to $\pm 5^{\circ} \mathrm{C}$ assuming a seafloor temperature of $0^{\circ} \mathrm{C}$ and a geothermal gradient of $25^{\circ} \mathrm{C} / \mathrm{km}$ below the seafloor at each site. Pressure gradients were calculated as the sum of the hydrostatic and lithostatic pressure at each site using the seawater densities and wet sediment bulk densities provided by Barron, Larsen, et al. (1989). The use of apparent equilibrium constants allows the use of the measured total concentrations in the calculation of saturation indices; carbonate ion concentrations were calculated by assuming that the carbonate alkalinity is equal to the titration alkalinity.

In addition, saturation indices for calcite and aragonite were also calculated using the EQ3NR geochemical speciation-solubility program developed by Wolery $(1979,1983)$. The EQ3NR program models the thermodynamic state of an aqueous solu- 

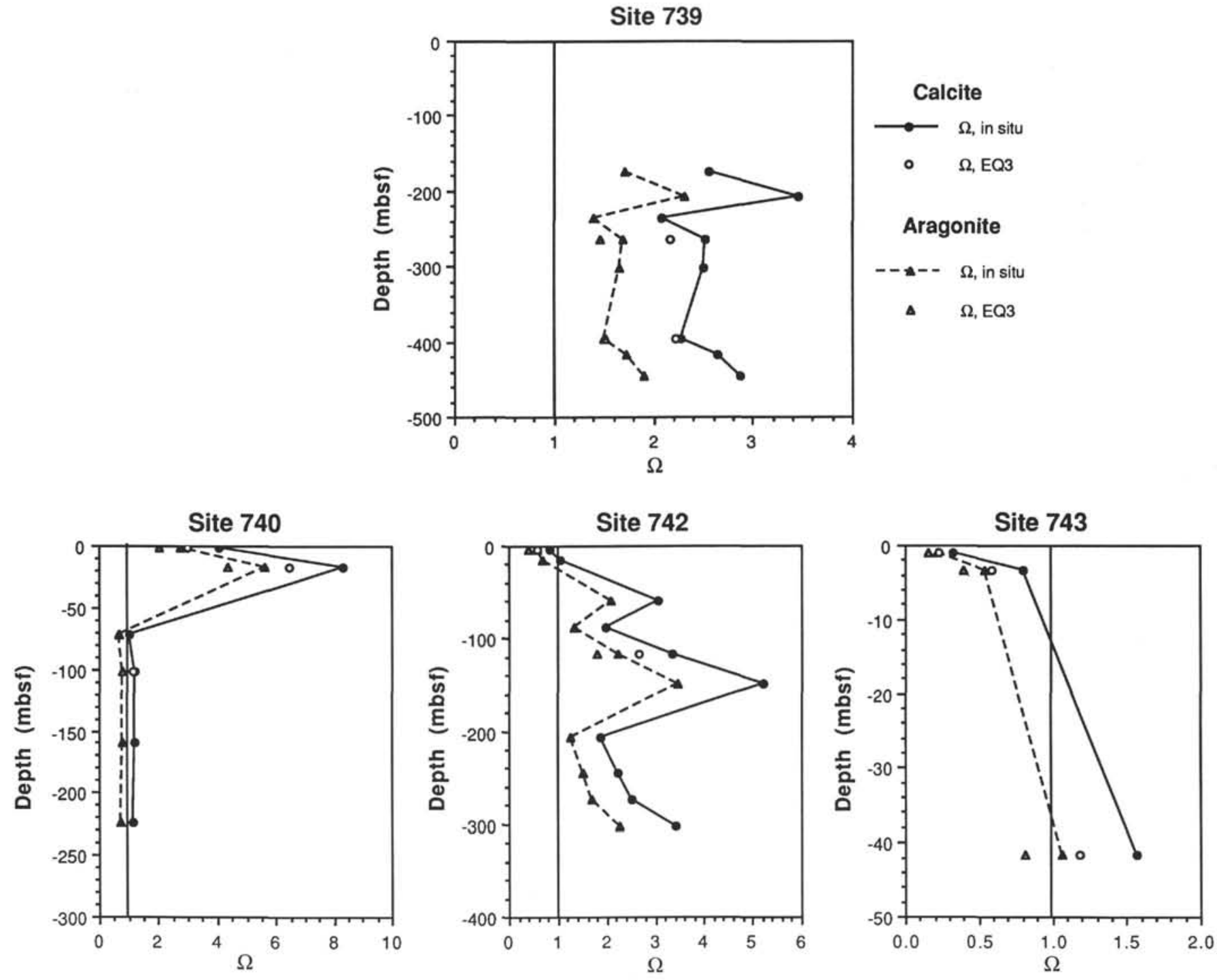

Figure 12. Saturation indices for aragonite and calcite calculated for each of the Prydz Bay coring sites using the apparent dissociation constants and solubility products given by Gieskes (1974) and the EQ3NR geochemical speciation-solubility program developed by Wolery (1979, 1983). The "in situ" curves were calculated using the equations provided by Gieskes (1974) and the estimated in-situ values of temperature and pressure for each of the interstitial-water samples. The "EQ3" data were calculated at the estimated in situ temperatures and a pressure of 1 atm. A detailed discussion of the results is given in the text.

tion by calculating the distribution of aqueous species, including simple ions, ion pairs, and aqueous complexes (Wolery, 1983). The activities of a wide variety of aqueous species were calculated using the total concentration data, the solution density and salinity, and the temperature of the system. Average seawater concentrations of aluminum and boron were included in the input data to make the sample compositions more realistic and to allow the program to calculate the saturation indices of common aluminosilicate minerals. For this study, the temperatures were estimated in the same way as the previous method, and a pressure of $1 \mathrm{~atm}$ was used for all samples. Thus, the EQ3NR results do take into account the effect of ionic interactions on mineral solubility in aqueous solutions, but they do not account for the effects of pressure on carbon dioxide speciation and solid carbonate solubility. The saturation indices of aragonite and calcite calculated using EQ3NR program are also plotted in Figure 12. The small number of calculations made by this method is a result of the need for a complete set of analyses on each sample. In each case, the saturation indices calculated by the EQ3NR program are lower than those calculated using the in-situ pressure estimates and the apparent equilibrium constants (Fig. 12). This is probably a result of the importance of sodium and magnesium bicarbonate complexes indicated by the EQ3NR calculations.

Thermodynamic modeling of carbonate equilibria in the Prydz Bay interstitial waters indicates that bottom waters seaward of Site 740 are undersaturated with respect to calcite and aragonite. The shallowest interstitial water samples at Sites 741, 742, and 743 are undersaturated with respect to both aragonite and calcite. Only at Site 740 , where bacterial sulfate reduction is occurring near the sediment/water interface, is the depositional environment amenable to the preservation of these minerals (Fig. 12). However, at all of the sites seaward of Site 740, the interstitial waters become supersaturated with respect to both calcite and aragonite with increasing depth below the seafloor (Fig. 12). These results support the possibility that the alkalinity de- 
creases measured at each site are a result of calcium carbonate precipitation.

\section{Strontium Isotope Analyses at Site 739}

Additional information on the state of carbonate equilibria in Prydz Bay sediments comes from strontium analyses of both interstitial waters and biogenic calcium carbonate from Site 739.

Analyses of four interstitial water samples from 27.05 to 264.6 mbsf at Site 739 revealed strontium concentrations ranging from 160.2 to $181.9 \mu \mathrm{M}$ (mean $=154.6 \mu \mathrm{M}$, s.d. $=21.5$ $\mu \mathrm{M})$ and ${ }^{87} \mathrm{Sr} /{ }^{86} \mathrm{Sr}$ of 0.710341 to 0.711304 (mean $=0.710708$, s.d. $=0.000448$; E. Martin, pers. comm., 1990). These values are significantly higher than those of typical ocean waters (e.g., $90 \mu \mathrm{M}$ and 0.70906; Faure, 1986). Continental crustal materials are the only known sources of strontium with ${ }^{87} \mathrm{Sr} /{ }^{86} \mathrm{Sr}$ values greater than seawater. The relatively high pore-water ${ }^{87} \mathrm{Sr} /{ }^{86} \mathrm{Sr}$ values at Site 739 indicate that a substantial portion of the strontium added to the pore waters was derived from the alteration of clastic silicates in the sediments.

An important feature of the calcium carbonate saturation data plotted in Figure 12 is that calcite is thermodynamically more stable than aragonite in the presence of all of the pore-water samples used for these calculations. Therefore, even though most of the Prydz Bay interstitial waters are either near saturation or super saturated with respect to both minerals, aragonite will have a tendency to recrystallize to calcite.

Strontium in the interstitial waters of sediments at Site 739 can be considered to have three sources, (1) seawater, (2) terrigenous detritus $\left({ }^{87} \mathrm{Sr} /{ }^{86} \mathrm{Sr} \sim 0.720\right.$; Faure, 1986), and (3) calcium carbonate recrystallization $\left({ }^{87} \mathrm{Sr} /{ }^{86} \mathrm{Sr} \sim 0.708\right.$; Faure, 1986). The relative contributions of these sources can be calculated from the following equations:

$$
\begin{gathered}
0.708 \mathrm{x}+0.720 \mathrm{y}+0.70906(90 \mu \mathrm{M} / 154.6 \mu \mathrm{M})=0.710708 \\
\mathrm{x}+\mathrm{y}+(90 \mu \mathrm{M} / 154.6 \mu \mathrm{M})=1 \\
\mathrm{x}=0.244, \mathrm{y}=0.174
\end{gathered}
$$

where $\mathrm{x}$ is the strontium fraction derived from calcium carbonate recrystallization and $y$ is the fraction derived from the alteration of terrigenous debris. The values of $\mathrm{x}$ and $\mathrm{y}$ derived from equations 7 and 8 should be treated as minimum values considering that the original seawater incorporated in the sediments must have had a lower ${ }^{87} \mathrm{Sr} /{ }^{86} \mathrm{Sr}$ value than modern seawater and that the siliciclastic ${ }^{87} \mathrm{Sr} /{ }^{86} \mathrm{Sr}$ values might be lower than 0.720 . Given the fact that all of the interstitial-water samples from Site 739 shown in Figure 12 are supersaturated with respect to calcite and aragonite, it might seem unusual that $24 \%$ of the dissolved strontium has a calcium carbonate source. However, much of the calcium carbonate in the glacial sediments in Prydz Bay is aragonitic (Thierstein et al., this volume). Aragonite commonly incorporates much more strontium into its crystalline lattice than does calcite (Deer et al., 1978). Therefore, recrystallization of aragonite to calcite, which is favored in all of the Prydz Bay pore-water samples (Fig. 12), will release strontium to the surrounding water without affecting dissolved calcium concentrations.

In summary, the results of the alkalinity model, the thermodynamic calculations, and the strontium data indicate that (1) ocean bottom waters seaward of Site 740 are undersaturated with respect to both calcite and aragonite, (2) interstitial waters at each site become saturated or supersaturated with respect to calcite and aragonite with increasing depth, (3) precipitation of calcium carbonate reduces the alkalinity of the pore waters with increasing depth, (4) recrystallization of aragonite to calcite ac- counts for $24 \%$ of the pore-water strontium and is probably responsible for the apparently high ${ }^{87} \mathrm{Sr} /{ }^{86} \mathrm{Sr}$ values obtained from analyses of aragonitic mollusks at Site 739 (E. Martin, pers. comm., 1990), and (5) calcium carbonate dissolution is not the cause of the observed calcium gradients in the interstitial waters of Prydz Bay sediments.

\section{Cation Gradients}

Weathering of unstable terrestrial debris and cation exchange between clay minerals and pore fluids are the most probable chemical processes affecting the distributions of major cations in the interstitial waters of Prydz Bay sediments. Typical downhole interstitial-water chemical shifts include an increase in calcium concentrations, decreases in magnesium, potassium, and sodium concentrations, and a decrease in $2^{18} \mathrm{O}$ of the water solvent. The most abundant, potentially unstable aluminosilicates in the glacial sediments are feldspars. Alteration of feldspars to smectites would be favored in an alkaline solution (Krauskopf, 1979). This may be the primary reaction responsible for the increase in calcium concentrations, decrease in magnesium concentrations, and ${ }^{18} \mathrm{O}$ abundances in the pore waters. In addition, the dissolution of feldspars would appear to be the most plausible source of the radiogenic pore-water strontium discovered at Site 739 . Eventually the interstitial waters become saturated with respect to calcite and some of the calcium ions are consumed (Sites 739 and 742). Cation exchange between smectites and coexisting fluids might favor the uptake of sodium by the clays and the release of calcium to the pore waters (Deer et al., 1978). The decrease in dissolved potassium at Sites 739, 740, 742 , and 743 may be related to illite formation at deeper levels and higher temperatures (Hambrey et al., this volume). Specification of reactions is speculative at this stage of the study because of the lack of solid-phase chemistry. They are simply presented as the most probable processes responsible for the observed interstitial-water chemical gradients based on previous studies and the available mineralogical information and core descriptions.

\section{ACKNOWLEDGMENTS}

This work was supported by a grant from the JOI U.S. Science Advisory Committee. I would like to thank the crew and technicians aboard the JOIDES Resolution for their help in the collection, processing, and analysis of the samples. Teresa Presser of the U.S. Geological Survey, Menlo Park, CA, was kind enough to allow me to use her atomic absorption spectrophotometer for the pore water sodium and potassium analyses. Stable isotope analyses were performed at the laboratory of the Isotope Geology Branch of the U.S. Geological Survey, Menlo Park, CA. Ellen Martin of the Scripps Institution of Oceanography, $\mathrm{La}$ Jolla, CA, generously shared her strontium isotope data for use in this report. John Barron, Bjorn Burchardt-Larsen, James C. Ingle, Jr., Ole Stig Jacobsen, Birger Larsen, and James R. O'Neil provided helpful reviews of an earlier version of the manuscript. Discussions with Ingle, George Parks, and Anders Solheim were instrumental in shaping the final version of the manuscript. The author takes full responsibility for the interpretations offered in this report.

\section{REFERENCES}

Barron, J., Larsen, B., et al., 1989. Proc. ODP, Init. Repts., 119: College Station, TX (Ocean Drilling Program).

Bath, A., and Shackleton, N., 1984. Oxygen and hydrogen isotope studies in squeezed pore waters, Deep Sea Drilling Project Leg 74, Hole 525B: evidence for mid-Miocene ocean isotopic change. In Moore, T. C., Jr., Rabinowitz, P. D., et al., Init. Repts. DSDP, 74: Washington (U.S. Govt. Printing Office), 697-699.

Berner, R. A., 1980. Early Diagenesis: A Theoretical Approach: Princeton, NJ (Princeton Univ. Press). 
Coleman, M. L., Shepherd, T. J., Durham, J. J., Rouse, J. E., and Moore, G. R., 1982. Reduction of water with zinc for hydrogen isotope analysis. Anal. Chem., 54:993-995.

Craig, H., 1961. Isotopic variations in meteoric waters. Science, 133: $1702-1703$.

Craig, H., and Gordon, L. I., 1965. Deuterium and oxygen 18 variations in the ocean and the marine atmosphere. In Tongiorgi, E. (Ed.), Stable Isotopes in Oceanographic Studies and Paleotemperatures, Spoleto, 1965: Pisa (Consiglio Nazionale delle Ricerche, Laboratorio di Geologia Nucleare), 9-130.

Deer, W. A., Howie, R. A., and Zussman, J., 1978. An Introduction to the Rock Forming Minerals: New York (Longman Group).

Epstein, S., and Mayeda, T., 1953. Variation of $\mathrm{O}^{18}$ content of waters from natural sources. Geochim. Cosmochim. Acta, 4:213-224.

Faure, G., 1986. Principles of Isotope Geology: New York (Wiley).

Friedman, I., 1953. Deuterium content of natural water and other substances. Geochim. Cosmochim. Acta, 4:89-103.

Gieskes, J. M., 1974. The alkalinity-total carbon dioxide system in seawater. In Goldberg, E. D. (Ed.), The Sea (Vol. 5): New York (Wiley), 527-568.

Gieskes, J. M., and Peretsman, G., 1985. Water chemistry procedures aboard JOIDES Resolution-some comments. ODP Tech. Note, 5.

Kendall, C., and Coplen, T. B., 1985. Multisample conversion of water to hydrogen by zinc for stable isotope determination. Anal. Chem., 57:1437-1440.
Krauskopf, K. B., 1979. Introduction to Geochemistry. (2nd ed): New York (McGraw-Hill).

Leg 119 Shipboard Scientific Party, 1988. Early glaciation of Antarctica. Nature, 333:303-304.

Sholkovitz, E. R., 1973. Interstitial water chemistry of the Santa Barbara Basin sediments. Geochim. Cosmochim. Acta., 37:2043-2073.

Stagg, H.M.J., 1985. The structure and origin of Prydz Bay and MacRobertson Shelf, East Antarctica. Tectonophysics, 114:315-340.

Tanweer, A., Hut, G., and Burgman, J. O., 1988. Optimal conditions for the reduction of water hydrogen by zinc for mass spectrometric analysis of the deuterium content. Chem. Geol., 73:199-203.

Welhan, J. A., 1987. Stable isotope hydrology. In Kyser, T. K. (Ed.), Short Course in Stable Isotope Geochemistry of Low Temperature Fluids. Mineral. Assoc. Canada Short Course, 13:129-161.

Wolery, T. J., 1979. Calculation of Chemical Equilibria between Aqueous Solutions and Minerals. EQ3/EQ6 Software Package. Livermore, CA (Lawrence Livermore Laboratory, Univ. of Calif.).

1983. EQ3NR: a Computer Program for Geochemical Aqueous Speciation-Solubility Calculations. User's Guide and documentation. Livermore, CA (Lawrence Livermore Laboratory, Univ. of Calif.).

Date of initial receipt: 8 December 1989

Date of acceptance: 23 July 1990

Ms 119B-170 